\title{
Bone char from an invasive aquatic species "devilfish" as a sustainable adsorbent for the removal of fluoride in water for human consumption
}

\section{Sergio Armando Cruz-Briano}

Universidad Autónoma de San Luis Potosí: Universidad Autonoma de San Luis Potosi

Nahum Andrés Medellín-Castillo ( $\square$ nahum.medellin@uaslp.mx )

Universidad Autonoma de San Luis Potosi https://orcid.org/0000-0001-9245-8016

Arturo Torres-Dosal

El Colegio De La Frontera Sur: El Colegio de la Frontera Sur

Roberto Leyva-Ramos

Universidad Autónoma de San Luis Potosí: Universidad Autonoma de San Luis Potosi

Juan Carlos Moreno-Piraján

Universidad de Los Andes

Liliana Giraldo-Gutiérrez

Universidad Nacional de Colombia

César Arturo llizaliturri-Hernández

Universidad Autónoma de San Luis Potosí: Universidad Autonoma de San Luis Potosi

Paola Elizabeth Díaz-Flores

Universidad Autónoma de San Luis Potosí: Universidad Autonoma de San Luis Potosi

Simón Yobanny Reyes-López

Universidad Autónoma de Ciudad Juárez: Universidad Autonoma de Ciudad Juarez

Raúl Ocampo-Pérez

Universidad Autónoma de San Luis Potosí: Universidad Autonoma de San Luis Potosi

Jenny Paola Rodríguez-Estupiñan

Universidad de Los Andes

Cristóbal Aldama-Aguilera

Universidad Autónoma de San Luis Potosí: Universidad Autonoma de San Luis Potosi

\section{Research Article}

Keywords: fluorides, bone char, devilfish, drinking water, thermodynamic adsorption properties, alien acuatic species

Posted Date: February 19th, 2021 
DOl: https://doi.org/10.21203/rs.3.rs-198271/v1

License: (c) (1) This work is licensed under a Creative Commons Attribution 4.0 International License. Read Full License 


\section{Bone char from an invasive aquatic species "devilfish" as a sustainable adsorbent for} the removal of fluoride in water for human consumption

Sergio Armando Cruz-Briano ${ }^{\mathrm{a}, \mathrm{b}^{*}}$, Nahum Andrés Medellín-Castillo ${ }^{\mathrm{a}, \mathrm{b}^{*}}$, Arturo Torres-Dosal $^{\mathrm{c}}$ Roberto Leyva-Ramos ${ }^{\mathrm{d}}$, Juan Carlos Moreno-Piraján ${ }^{\mathrm{e}}$, Liliana Giraldo-Gutiérrez ${ }^{\mathrm{f}}$, César Arturo Ilizaliturri-Hernández ${ }^{\mathrm{a}}$, Paola Elizabeth Diaz-Flores ${ }^{\mathrm{a}}$, Simon Yobanny Reyes-López ${ }^{\mathrm{g}}$, Raúl Ocampo-Pérez ${ }^{\mathrm{d}}$, Jenny Paola Rodríguez-Estupiñan ${ }^{\mathrm{e}}$, Cristóbal Aldama-Aguilera ${ }^{\mathrm{b}}$ ${ }^{a}$ Programa Multidisciplinario de Posgrado en Ciencias Ambientales, Agenda Ambiental, Universidad Autónoma de San Luis Potosí, San Luis Potosí, S.L.P., 78290, México ${ }^{b}$ Centro de Investigación y Estudios de Posgrado, Facultad de Ingeniería, Universidad Autónoma de San Luis Potosí, San Luis Potosí, S.L.P., 78290, México

${ }^{c}$ El Colegio de la Frontera Sur (ECOSUR), Carretera Panamericana y Periférico Sur s/n, Barrio María Auxiliadora, San Cristóbal de las Casas, Chiapas, México, C.P. 29290.

${ }^{d}$ Facultad de Ciencias Químicas, Universidad Autónoma de San Luis Potosí, San Luis Potosí, S.L.P., 78260, México

${ }^{e}$ Departamento de Química, Facultad de Ciencias, Universidad de los Andes. Bogotá, 111711, Colombia

${ }^{f}$ Departamento de Química, Facultad de Ciencias, Universidad Nacional de Colombia. Bogotá, 111321, Colombia ${ }^{g}$ Instituto de Ciencias Biomedicas, Universidad Autonoma de Ciudad Juarez, Cd. Juarez, Chihuahua, 32300, México

*Corresponding author:

E-mail address:

nahumanca@hotmail.com; nahum.medellin@uaslp.mx 


\section{ABSTRACT}

In this study, bone chars were obtained from an alien acuatic species "devilfish" bones by pyrolysis of $500-800{ }^{\circ} \mathrm{C}$. Bone chars were evaluated as a sustainable adsorbent of fluoride, it was found pyrolysed bone char at $500{ }^{\circ} \mathrm{C}$ adsorbed the most amount of fluoride. The effect of $\mathrm{pH}$ indicated that the adsorption capacity increased as the $\mathrm{pH}$ decreased. Thermodynamic parameters of fluoride adsorption on devilfish bone chars were estimated as $\Delta \mathrm{H}^{\circ}=7.213 \mathrm{~kJ} \mathrm{~mol}^{-}$ ${ }^{1}, \Delta \mathrm{G}^{\circ}=23.61 \mathrm{~kJ} \mathrm{~mol}^{-1}$ and $\Delta \mathrm{S}^{\circ}=103.4 \mathrm{~J} \mathrm{~mol}^{-1} \mathrm{~K}^{-1}$ indicating that adsorption is endothermic, spontaneous and with great affinity of fluoride on bone char from devilfish. The fluoride desorption study showed that fluoride is desorbed from the material of 0.24 to $20.06 \%$, so the adsorption is considered to be partly reversible. The regeneration of the bone char at 400,500 and $600{ }^{\circ} \mathrm{C}$ was studied and it was noted that its adsorption capacity decreases slightly so it could be considered appropriate for the use in water treatment technologies. Adsorption of fluorides from drinking well water of a rural community with dental fluorosis problems and high levels of fluoride in water, revealed that by increasing the amount of the bone char of 0.05 to $0.8 \mathrm{~g}$, the disposal of fluoride increases from 69.1 to $98.7 \%$. Lastly, it was established that the bone char synthesized from devilfish is a low-cost, viable a sustainable material to remove fluorides from water and represents an environmental management strategy of this alien species.

Keywords: fluorides; bone char; devilfish; drinking water; thermodynamic adsorption properties; alien acuatic species 


\section{Introduction}

The presence of invasive aquatic specie affects the imbalance of biodiversity and it is a problem detected in ecosystems worldwide, also it has even generated economic collateral consequences (Thomas et al. 2019) and are the most significant contributors to the extinction of native species (Garcia-Gonzales et al. 2017). Both the number and distribution of invasive species are increasing in various regions of the world.

In addition, the growing global commerce in ornamental aquarium fish is one of the most important routes for aquatic bioinvasion with non-native species (Bijukumar et al. 2015). Other pathways of introduction include drainage of water containing organisms from public tanks and aquariums, biocontrol and aquaculture activities (García-Martínez et al. 2014).

In Mexico, a biological invasion problem has developed over the last 20 years, caused by the family Loricariidae, often referred to as pleco, plecos or devilfish (Garcia-Gonzales et al. 2017; Medellin-Castillo et al. 2020). This family is one of the most diverse, with 716 species described. They are endemic freshwater species from South America, Costa Rica and Panama and are native to the Amazon River basin (Garcia-Gonzales et al. 2017; Ríos-Muñoz 2015; Rosnaeni et al. 2017). Because of their detritivorous qualities, some of these species have been commercialized as ornamental fish and algae controllers. This has promoted their introduction into rivers and lakes in warm climate regions, either in a controlled or accidental manner.

Devilfish displace other species, some of which are endemic, in various ways, including incidental ingestion of their eggs and competition for algae and detritus (Medellin-Castillo et al. 2020; Moncayo-Fernández et al. 2017). They also cause deterioration in water quality due to the suspension of sediment caused by their nesting habits, which consist of digging large galleries (Sandoval-Huerta et al. 2012). 
Currently, the devilfish is distributed throughout Mexico, including the Mezcala, Balsas, Grijalva and Usumacinta rivers and their slopes, as also the Infiernillo Dam ( Medellin-Castillo et al. 2020; Moncayo-Fernández et al. 2017).

Among the uses given to these fish are as food for the general population, or to obtain byproducts as fertilizers, fish silage as a feed supplement for livestock, and fishmeal for fish feed Human consumption as a feed supplement is possible, although further study is required as certain species of devilfish tend to accumulate heavy metals, which has discouraged their consumption (Maldonado et al. 2015).

Fluoride pollution of water is a major issue worldwide (Akafu et al. 2019; Fan et al. 2019; Kumar et al. 2019; Medellin-Castillo et al. 2020). In drinking water, a fluoride concentration between 0.5 to $1.0 \mathrm{mg} \mathrm{L}^{-1}$ can be considered beneficial to teeth and bones (Abeykoon et al. 2020; Medellín-Castillo et al. 2020; Quintáns-Fondo et al. 2019). Nevertheless, fluoride water intake above the World Health Organization (WHO) suggested dose (1.50 mg L $\left.\mathrm{m}^{-1}\right)$ causes significant health effects such as dental fluorosis, skeletal fluorosis and and even in severe cases, cancer (Abeykoon et al. 2020; Emmanuel et al. 2018; Jalil et al. 2019; Quintáns-Fondo et al. 2019).

Various technologies are available for the removal of fluorides, including precipitation, coagulation, reverse osmosis, ion exchange, and adsorption. Of all methods, adsorption is highly effective and economical for the reduction of excess fluoride in water (Abeykoon et al. 2020; Akafu et al. 2019; Alkurdi et al. 2019; Assaoui et al. 2020; Emmanuel et al. 2018; Fan et al. 2019), and it uses a variety of adsorbent materials, including clay, soil, organic matter, alumina, zeolites, nanomaterials, activated carbon and bone char (Alkurdi et al. 2019; Teusner et al. 2016). Bone chars have been widely considered in fluoride removal and have gained considerable attention due to their cheapness, high availability, easy preparation and high adsorption capacity (Alkurdi et al. 2019; Medellin-Castillo et al. 2020). 
In this study, we seek to obtain a management alternative for the use of an invasive acuatic species that does not yet have any economic value. Therefore, bone chars from devilfish were prepared to study the influence of the temperature of pyrolysis on the fluoride adsorption capacity of bone chars. Also, the influence of $\mathrm{pH}$ and temperature on the adsorption capacity was studied and thermodynamic properties of this process were determined. The thermal regeneration of bone char saturated with fluoride at 400,500 and $600{ }^{\circ} \mathrm{C}$ was evaluated for the for the design of water treatment technologies. Finally, the use of these materials in the drinking well water of a rural community was studied.

\section{Material and Methods}

\subsection{Collection of fish and extraction of bones}

The fish used in this study were fished in the municipality of Tenosique in the State of Tabasco in Mexico, located in the Usumacinta River region. This site was selected because the presence of devilfish has been reported to be an environmental problem that has altered fishing in the region as well as affecting native species (Maldonado et al. 2015). Fig. 1 shows the location of the devilfish sampling site.

The organic matter contained in the fish was removed was removed from the bones using a solution prepared with a 3:1 ratio of deionized water and hydrogen peroxide. Bones were left to dry at room temperature and were labelled Bone. 

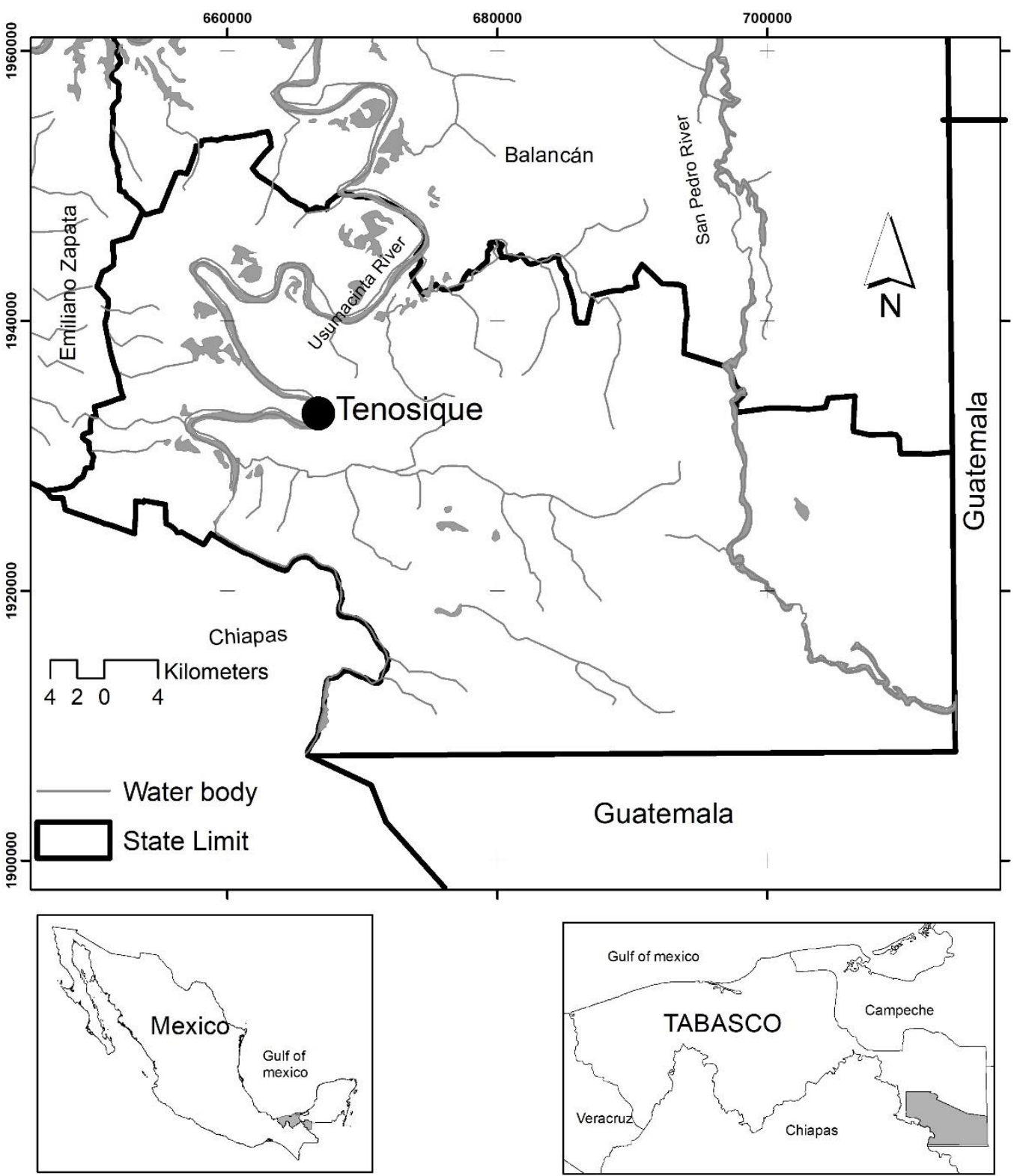

Fig. 1. Location of the devilfish collection site.

\subsection{Synthesis}

120 The synthesis of the bone chars by means of a pyrolysis process was conducted in a tube furnace 121 Carbolite, model CTF- $1200^{\circ} \mathrm{C}$, at temperatures of $400,500,600,700$ and $800{ }^{\circ} \mathrm{C}$, with a flow 122 of $\mathrm{N}_{2}$ of $100 \mathrm{~mL} \mathrm{~min}{ }^{-1}, 10{ }^{\circ} \mathrm{C} \mathrm{min}^{-1}$ and a pyrolysis time of one hour at the specified synthesis 123 temperature. 
The pyrolysed bones at 400, 500, 600, 700 and $800{ }^{\circ} \mathrm{C}$ were labelled as $\mathrm{C} 400, \mathrm{C} 500, \mathrm{C} 600$, C700 and C800, respectively.

The yield of the production of the bone chars, $\% \mathrm{R}$, was determined with the next equation:

$$
\% \mathrm{R}=\frac{\text { Dried weight of the bone chars }}{\text { Dried weight of the bones }} \times 100
$$

\subsection{Textural and physico-chemical properties}

The BET method was used to evaluate the textural properties of the materials obtained, as well as its precursor. The acidic and basic sites were obtained by the Boehm method.

The point zero charge $\mathrm{pH}$ PZC was determined by a method of salt addition (Ahmad et al. 2018; Medellin-Castillo et al. 2020).

The surface and morphology of the particles were observed in a SEM, JEOL JSM-6610, equipped with a microanalysis system EDS (Electron Dispersive Spectroscopy) Oxford, model 7279. The functional groups of the materials were identified using an FTIR spectrophotometer, Thermo Scientific brand, model Nicolet iS10. Infrared spectra were collected over a spectral range of 500 to $4000 \mathrm{~cm}^{-1}$.

Thermogravimetric analysis was completed using an analyzer Perkin Elmer, model Pyris Diamond.

The crystal structure was analyzed using an X-ray diffractometer (XRD), Bruker brand, Da Vinci model, with a radiation $\mathrm{CuK} \alpha(\lambda=0.15405 \mathrm{~nm})$.

\subsection{Adsorption of fluoride}

These data were obtained by conducting batch adsorption experiments, in which $0.2 \mathrm{~g}$ of the bone char with a $90 \mathrm{~mL}$ volume of a fluoride solution of initial concentrations between 2 and $60 \mathrm{mg} \mathrm{L}^{-1}$ was contacted for 7 days. The $\mathrm{pH}$ was set daily using 0.01 and $0.1 \mathrm{~N}$ solutions of 
$\mathrm{HNO}_{3}$ or $\mathrm{NaOH}$. The amount of fluoride on the bone char was estimated by means of a mass balance according to:

$$
\mathrm{q}=\frac{\mathrm{V}_{0}\left(\mathrm{C}_{0}-\mathrm{C}_{\mathrm{f}}\right)}{\mathrm{m}}
$$

where $\mathrm{q}$ is the mass of fluoride adsorbed in $\mathrm{mg} \mathrm{g}^{-1} ; \mathrm{V}_{0}$ is the initial volume in $\mathrm{L} ; \mathrm{C}_{0}$ is the initial concentration of fluoride in the solution in $\mathrm{mg} \mathrm{L}^{-1} ; \mathrm{C}_{\mathrm{f}}$ is the equilibrium fluoride concentration in $\mathrm{mg} \mathrm{L}^{-1}$ and $\mathrm{m}$ is the mass of bone char used in each experiment in $\mathrm{g}$.

\subsection{Desorption and regeneration}

Experimental data on the reversibility of the equilibrium of fluoride on bone char was obtained by first performing adsorption experiments, as described previously, at a solution $\mathrm{pH}$ of 5.0 and upon reaching adsorption equilibrium the desorption or reversibility step was performed, at $\mathrm{pH}$ of 5.0 or 9.0 .

The amount of fluoride remaining in te adsorbent was estimated by applying a mass balance:

$$
\mathrm{q}=\frac{\mathrm{V}_{\mathrm{o}} \mathrm{C}_{\mathrm{o}}+\mathrm{q}_{\mathrm{o}} \mathrm{m}-\mathrm{V}_{\mathrm{f}} \mathrm{C}_{\mathrm{f}}}{\mathrm{m}}
$$

where $\mathrm{q}_{0}$ is the amount of fluoride on the adsorbent at the outset of the desorption, $\mathrm{mg}^{-1}$.

Additionally, thermal regeneration of bone char synthesized at $500{ }^{\circ} \mathrm{C}$ saturated with fluoride was evaluated at temperatures of 400,500 and $600{ }^{\circ} \mathrm{C}$ using the same synthesis conditions as described in section 2.2. The materials were identified as CR400, CR500 and CR600, respectively. These materials were contacted with fluoride solutions to determine their adsorption capacity.

\subsection{Fluoride adsorption from drinking well water}

The adsorption of fluoride contained in the water of a well in La Laborcilla rural community in the municipality of Villa de Arriaga, San Luis Potosi in Mexico was studied (Fig. 2). The fluoride concentration of the drinking well water from this community had a concentration of 
$1744.7 \mathrm{mg} \mathrm{L}^{-1}$. Experimental data of the adsorption equilibrium were obtained using various masses 175 of bone char that varied from 0.05 to $0.8 \mathrm{~g}$, and a volume of $100 \mathrm{~mL}$ of water. The determination 176 of the amount of fluoride adsorbed was described in section 2.4. Also, the \% removal of total 177 hardness, chlorides and sulphates from water was evaluated as they can compete in fluoride 178 removal on bone char. The \% removal, \% Re, was defined according to the following equation

$$
\% \mathrm{Re}=\frac{\mathrm{C}_{0}-\mathrm{C}_{\mathrm{f}}}{\mathrm{C}_{0}} \times 100
$$

180 where $\mathrm{C}_{0}$ is the concentration of the anion in water and $\mathrm{C}_{\mathrm{f}}$ is the concentration to the end of the 181 adsorption experiment. 

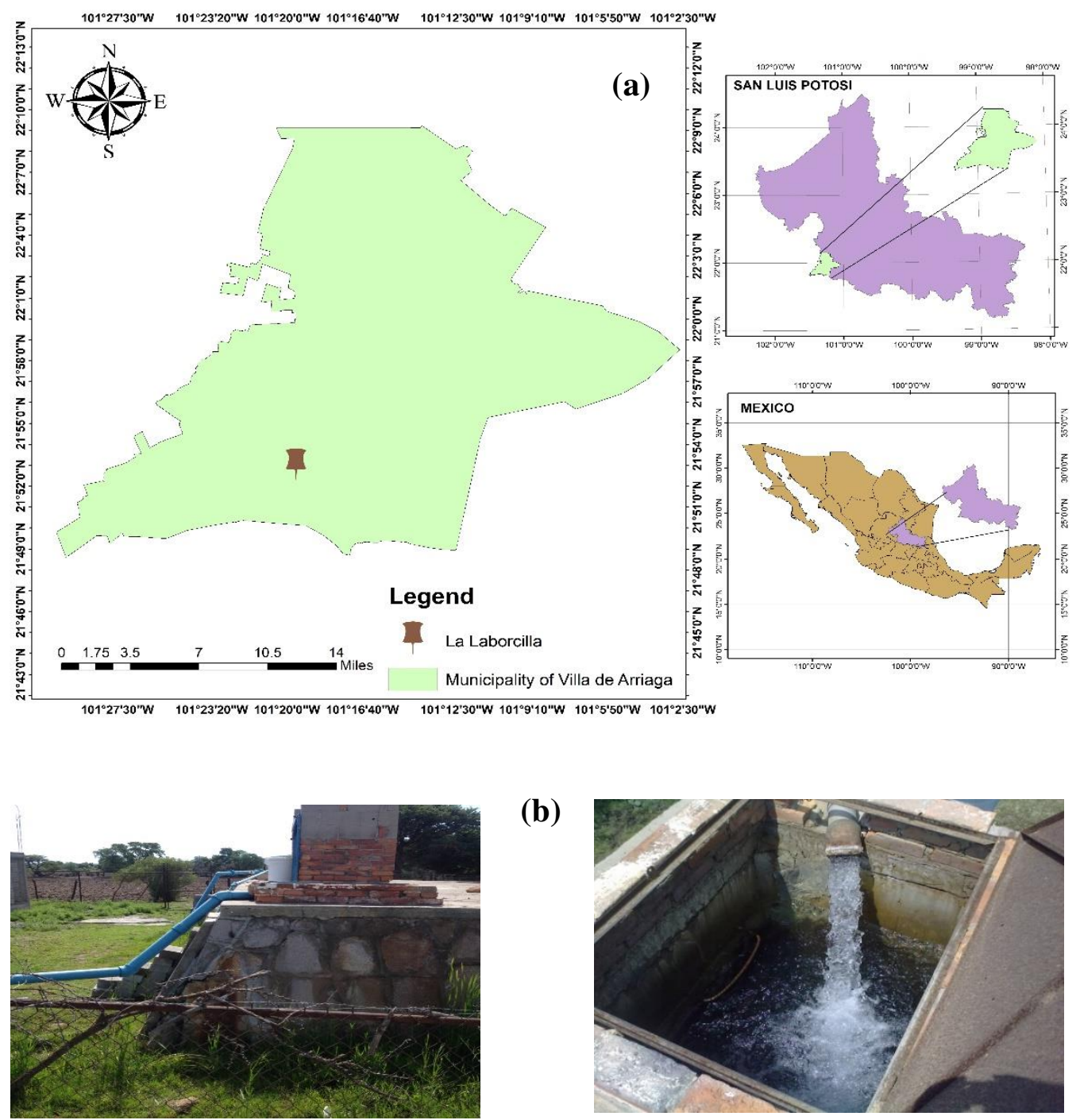

(b)

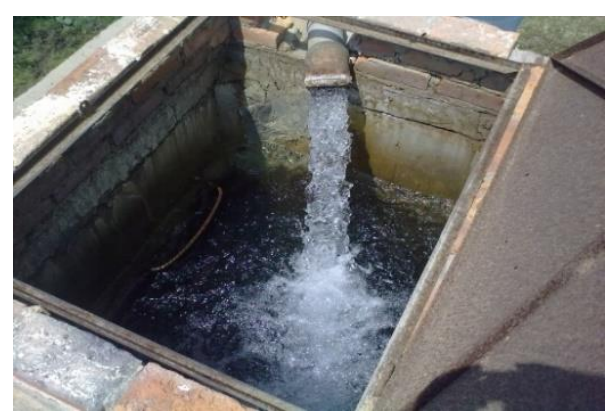

(c)

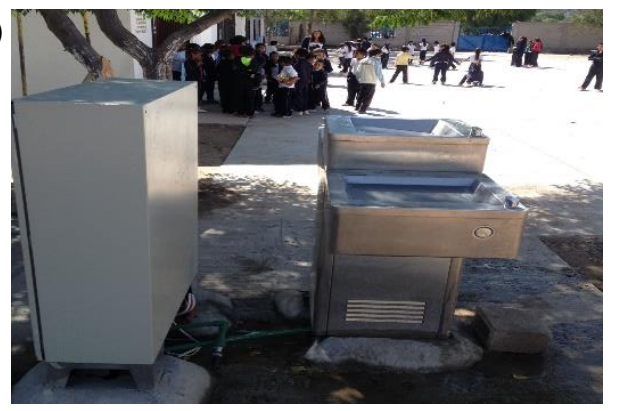

(d)

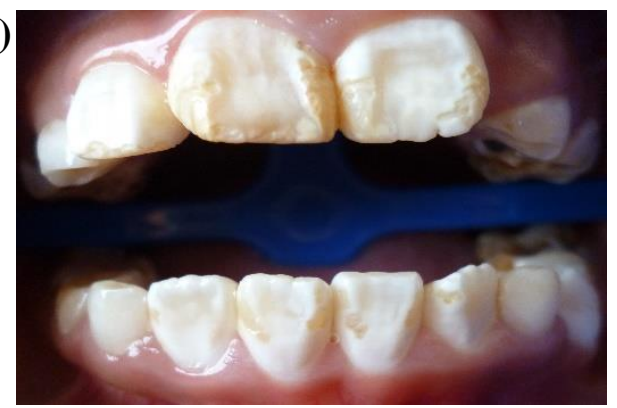

Fig. 2. Laborcilla, Villa de Arriaga: (a) Location; (b) Well; (c) Water dispenser; (d) Dental fluorosis. 


\section{Results and discussion}

189

190

191

192

193

197

198

\subsection{Yield of the synthesis}

During the pyrolysis of the devilfish bones samples (Bone), it could be observed that the percentage of yield, $\% \mathrm{R}$, obtained decreased when the synthesis temperature was raised from 400 to $800{ }^{\circ} \mathrm{C}$ (Table 1). This same behaviour has been observed by other authors (Purevsuren et al. 2017). This reduction can be attributed to the decomposition of some constituents of the bone char with the increases of the synthesis temperature, so that it loses more weight and consequently the $\% \mathrm{R}$ decreases.

Table 1. Percentage yield, $\% \mathrm{R}$, of bone char synthesis

\begin{tabular}{c|c|c|c}
\hline Sample & Raw material & $\begin{array}{c}\text { Synthesis } \\
\text { temperature, }\end{array}$ & $\mathbf{C}$ \\
\hline $\mathbf{C 4 0 0}$ & Bone & 400 & 50.50 \\
\hline $\mathbf{C 5 0 0}$ & Bone & 500 & 44.53 \\
\hline $\mathbf{C 6 0 0}$ & Bone & 600 & 43.92 \\
\hline $\mathbf{C 7 0 0}$ & Bone & 700 & 42.20 \\
\hline $\mathbf{C 8 0 0}$ & Bone & 800 & 40.90 \\
\hline
\end{tabular}

\subsection{Textural and physicochemical properties}

$\mathrm{N}_{2}$ adsorption isotherms measured at $77 \mathrm{~K}$ from the bones and pyrolysed bone chars at different temperatures are shown in Fig. 3.

The $\mathrm{N}_{2}$ adsorption isotherm of sample Bone (Fig. 3a) showed that it is type IIb, which corresponds to non-rigid aggregates, cements, pigments. Furthermore, it presents a hysteresis loop of type $\mathrm{H} 3$ which is attributed to a possible interparticle condensation. On the other hand, $\mathrm{N}_{2}$ adsorption isotherms for all bone chars are characteristic of mesoporous solids and correspond to IVa type isotherms. These results are consistent with those reported by other authors for bone chars (Isaacs-Páez et al., 2019). 

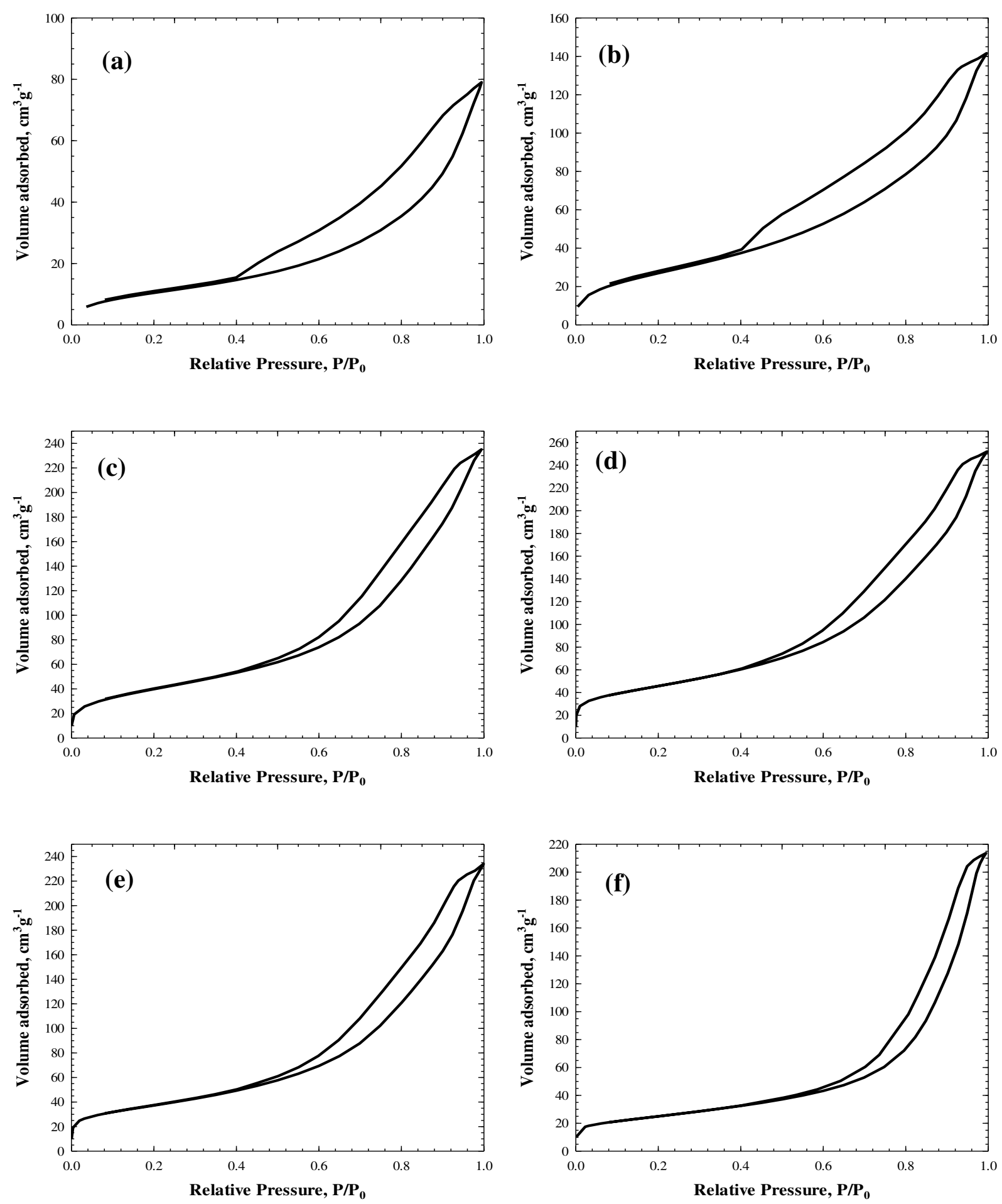

Fig. 3. Nitrogen adsorption isotherms at $77 \mathrm{~K}$ of: (a) Bone; (b) C400; (c) C500; (d) C600; (e)

$$
\text { C700; (f) C800 }
$$

Table 2 shows the textural properties of sample Bone and the synthesized bone chars. These results reveal that the specific area and pore volume of samples increases by increasing the 
pyrolysis temperature from 400 to $600{ }^{\circ} \mathrm{C}$ and then decreases by increasing the temperature

213 from 600 to $800{ }^{\circ} \mathrm{C}$. Thus, for this study it was observed that pyrolysis at 500 and $600{ }^{\circ} \mathrm{C}$

214 favored the increase in the specific area while there was a decrease at temperatures of 600 to

$800{ }^{\circ} \mathrm{C}$ which is attributed to the dehydroxylation of hydroxyapatite (Alkurdi et al. 2019).

Table 2. Textural, physical and chemical properties of materials from devilfish

\begin{tabular}{c|c|c|c|c|c|c}
\hline Sample & $\begin{array}{c}\text { Specific } \\
\text { surface } \\
\left(\mathbf{m}^{\mathbf{2}} \mathbf{g}^{-1}\right)\end{array}$ & $\begin{array}{c}\text { Pore } \\
\text { volume } \\
\left(\mathbf{c m}^{\mathbf{3}} \mathbf{g}^{-1}\right)\end{array}$ & $\begin{array}{c}\text { Average } \\
\text { pore } \\
\text { diameter } \\
(\mathbf{n m})\end{array}$ & pHPZC & $\begin{array}{c}\text { Basic sites } \\
\left(\mathbf{m e q} \mathbf{g}^{-1}\right)\end{array}$ & $\begin{array}{c}\text { Acidic sites } \\
\left(\mathbf{m e q ~}^{-1}\right)\end{array}$ \\
\hline $\mathbf{B o n e}$ & 40.35 & 0.1202 & 9.65 & 7.01 & 0.35 & 0.34 \\
\hline $\mathbf{C 4 0 0}$ & 102.5 & 0.24 & 7.36 & 6.74 & 0.40 & 0.62 \\
\hline $\mathbf{C 5 0 0}$ & 146.1 & 0.38 & 8.52 & 7.45 & 1.64 & 0.18 \\
\hline $\mathbf{C 6 0 0}$ & 163.0 & 0.40 & 8.34 & 7.75 & 0.40 & 0.06 \\
\hline $\mathbf{C 7 0 0}$ & 132.7 & 0.37 & 9.23 & 8.25 & 1.02 & 0.06 \\
\hline $\mathbf{C 8 0 0}$ & 88.46 & 0.34 & 13.1 & 8.46 & 1.03 & 0.05 \\
\hline
\end{tabular}

A comparison of the textural properties of sample Bone and its various bone chars shown that

the porosity of the bone chars developed significantly during pyrolysis, as a consequence of degradation of organic constituents by heat treatment and exposure of the pores in the hydroxyapatite structure (Medellin-Castillo et al. 2016). As a result, the pyrolysis at $500{ }^{\circ} \mathrm{C}$ dramatically improved the porosity and consequently the surface area.

The values of pore volume and diameter for each of the bone chars are within the range reported by other authors for bone chars (Alkurdi et al. 2019; Murillo et al. 2012; Nigri et al. 2019). According to the IUPAC classification, the materials obtained in this work are mesoporous materials since the average pore diameter varied in the interval from 7.36 to $13.1 \mathrm{~nm}$. concentration of acidic sites of $\mathrm{C} 400$ is higher than that of the basic sites, and they decrease as 
the temperature of pyrolysis rises, increasing the concentration of basic sites. This is due to the decomposition of certain bone components, such as organic matter and carbonates (Rogers and Daniels 2002) which promotes the formation of basic sites.

The concentrations of acidic and basic sites obtained in this work are in accordance with the values reported in other studies (Murillo et al. 2012). Although the bones used by these authors for synthesis were pork and chicken, the values coincide since the bones are mainly composed of hydroxyapatite, $70 \%$, in addition, $25 \%$ organic matter and $5 \%$ water (Kini and Nandeesh 2012; Terasaka et al. 2014).

\subsection{Effect of the pyrolysis temperature of bone char on the adsorption capacity}

The fluoride adsorption capacities at $\mathrm{pH} 7.0, \mathrm{~T}=25^{\circ} \mathrm{C}, \mathrm{C}_{0}=10 \mathrm{mg} \mathrm{L}^{-1}$ and $1 \mathrm{~g}$ of each bone char were compared, and the results are shown in Fig. 4. The fluoride concentration was established according to the values of the study well water and those reported in other areas by several authors (Alkurdi et al. 2019; Ledon et al. 2018; Otazo-Sánchez et al. 2020). The results show that at a concentration of $10 \mathrm{mg} \mathrm{L}^{-1}$ of fluorides in solution, the devilfish bone (Bone) has a fluoride adsorption capacity of $5.06 \mathrm{mg} \mathrm{g}^{-1}$ and this increases to 6.02 and $7.12 \mathrm{mg} \mathrm{g}^{-1}$ when the bone is pyrolysed at 400 and $500{ }^{\circ} \mathrm{C}$, respectively, however, it decreases to $5.55 \mathrm{mg} \mathrm{g}^{-1}$ when the pyrolysis temperature is elevated from 500 to $800{ }^{\circ} \mathrm{C}$. C500 was the sample with the highest fluoride adsorption capacity. This may be since it contains a higher concentration of base sites (Table 2) than the other bone char ones, so it was decided to perform the following experiments with this material. The results obtained for this study coincide with those reported by other authors (Bhatnagar et al. 2011; Kaseva 2006). The pretreatment of bones with hydrogen peroxide solutions prior to pyrolysis generates an increase in the specific area of the bone chars of up to 1.5 times with respect to those not treated with these solutions and the 
generation of pyrolysis subproducts or volatile matter is practically inexistent. Therefore, it can be considered that the conditions used in this study to carry out bone pyrolysis were adequate.

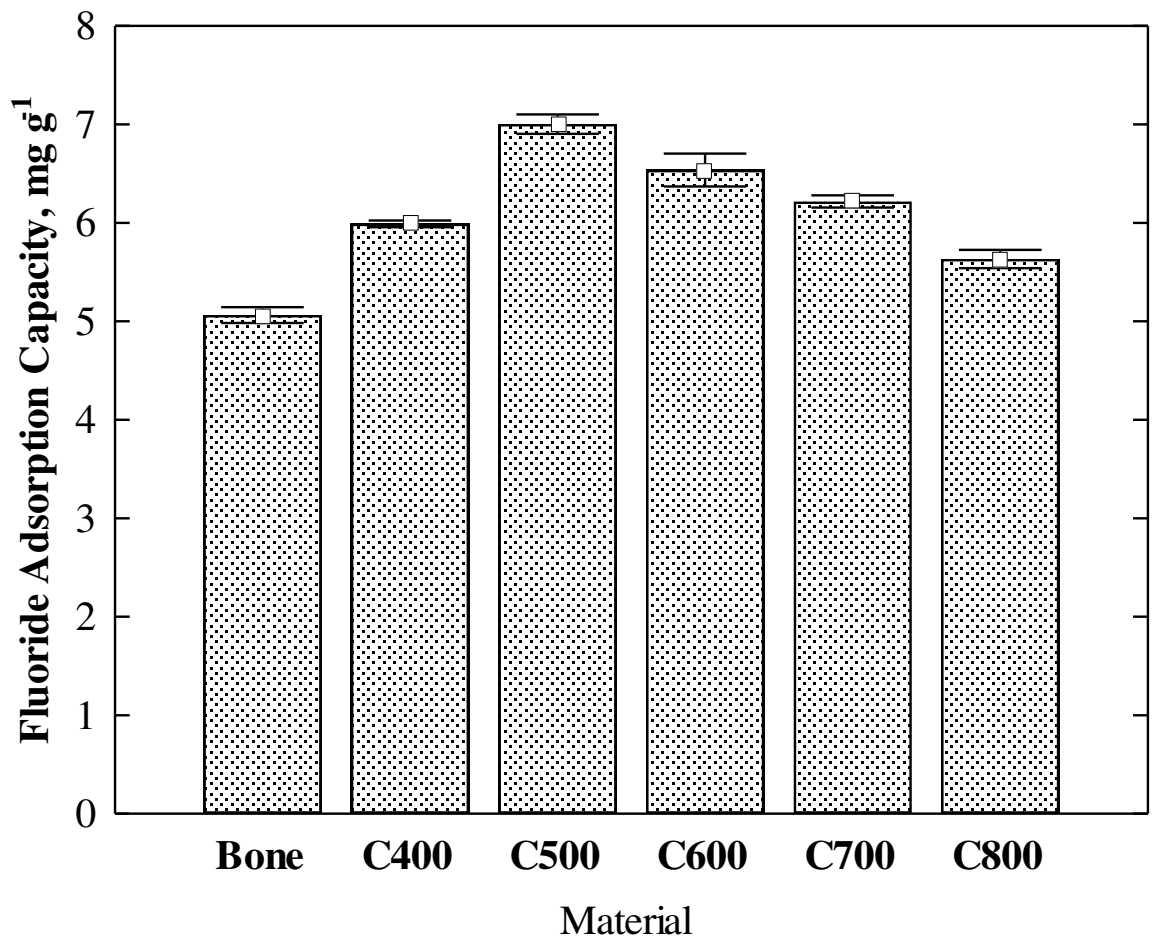

Fig. 4. Influence of the pyrolysis temperature on the fluoride adsorption capacity of Bone, C400, C500, C600, C700 and C800.

\subsection{SEM, IR, TGA and DRX Analysis}

Fig. 5 shows the SEM images of the surface of Bone, C500 and CF500 particles, respectively.

The images reveal that the Bone particles have irregular and slightly rough surfaces, in addition it is possible to observe an agglomeration of smaller particles on the surface, the C500 particles have a porous and irregular surface, and in addition, small crystalline particles are observed on its surface. Also, SEM images of the fluoride-saturated bone char (CF500) particles are observed. In addition, it does not show the crystalline particles that were observed in C500 due to fluoride adsorption on the surface. 


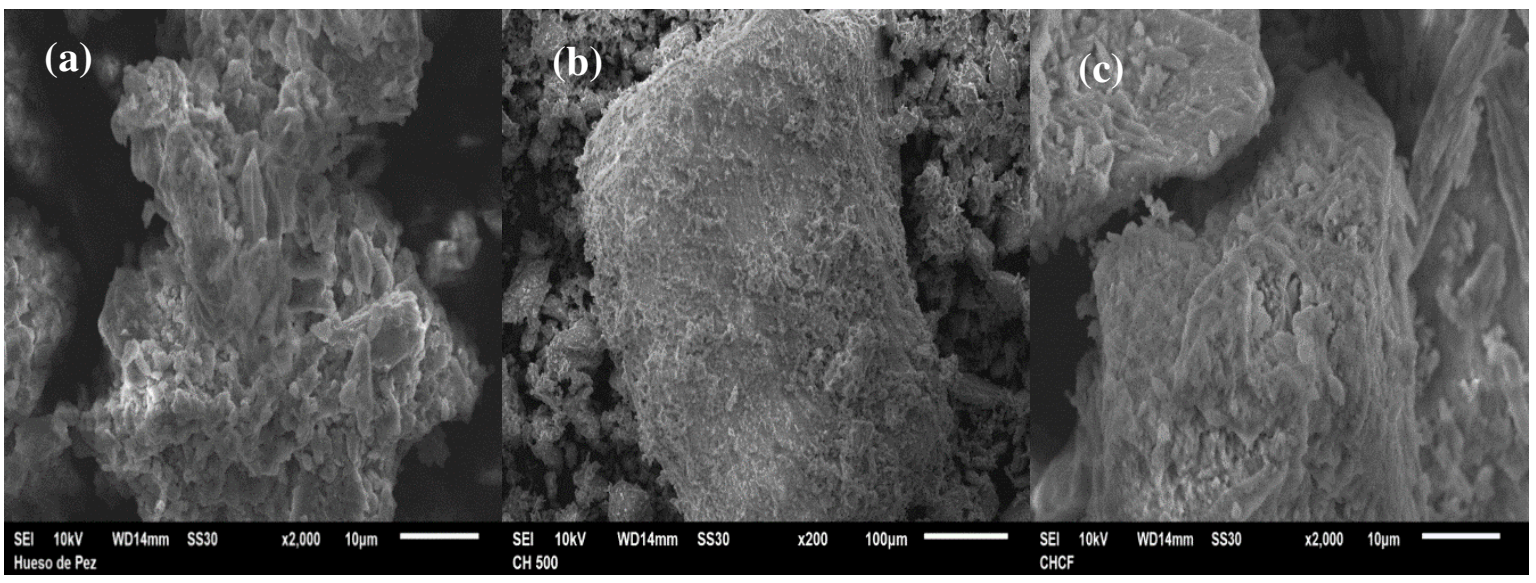

Fig. 5. SEM micrographs of (a) Bone; (b) C500 and (c) CF500.

272 The infrared spectra of the Bone, C500 and CF500 samples are shown in Fig. 6. In the infrared spectra the functional groups of $\mathrm{PO}_{4}{ }^{3-}, \mathrm{CO}_{3}{ }^{2-}, \mathrm{OH}^{-}$and organic compounds of each sample were identified. It can be seen that there is an increase in the intensity of the 556, 600, 961 and 1016 $\mathrm{cm}^{-1}$ bands, corresponding to the $\mathrm{PO}_{4}{ }^{3-}$ groups, when the bone is pyrolysed (C500) and at the same time these bands maintain their intensity when saturated with fluoride (CF500). In addition, the $3566 \mathrm{~cm}^{-1}$ band corresponding to the $\mathrm{OH}^{-}$increases when the Bone sample is pyrolysed, revealing the formation of hydroxyapatite, and this band is attenuated when saturated with fluoride, which may indicate an interaction between the hydroxyl groups of hydroxyapatite and fluoride (Nigri et al. 2019). The mass-loss (TG) and derivative mass-loss (DTG) curves of Bone, C500 and CF500 samples are exhibited in Fig. 7 and it is observed that the highest percentage of weight loss occurs with the B sample at $40 \%$, this due to the organic matter content which degrades in great proportion when submitted to the pyrolysis process at $500{ }^{\circ} \mathrm{C}$. The DTG curves show that the first weight loss for all three materials occurs below $100{ }^{\circ} \mathrm{C}$ and is associated with moisture loss, and from 270 to $640{ }^{\circ} \mathrm{C}$ the decomposition of proteins, fats, 286 collagen, and others (Bedin et al. 2017). At $700{ }^{\circ} \mathrm{C}$ there is a slight curve which is attributed to the decomposition of carbonates or to the dehydroxylation of hydroxyapatite (600 to $800{ }^{\circ} \mathrm{C}$ ) 

from 800 to $1000{ }^{\circ} \mathrm{C}$.

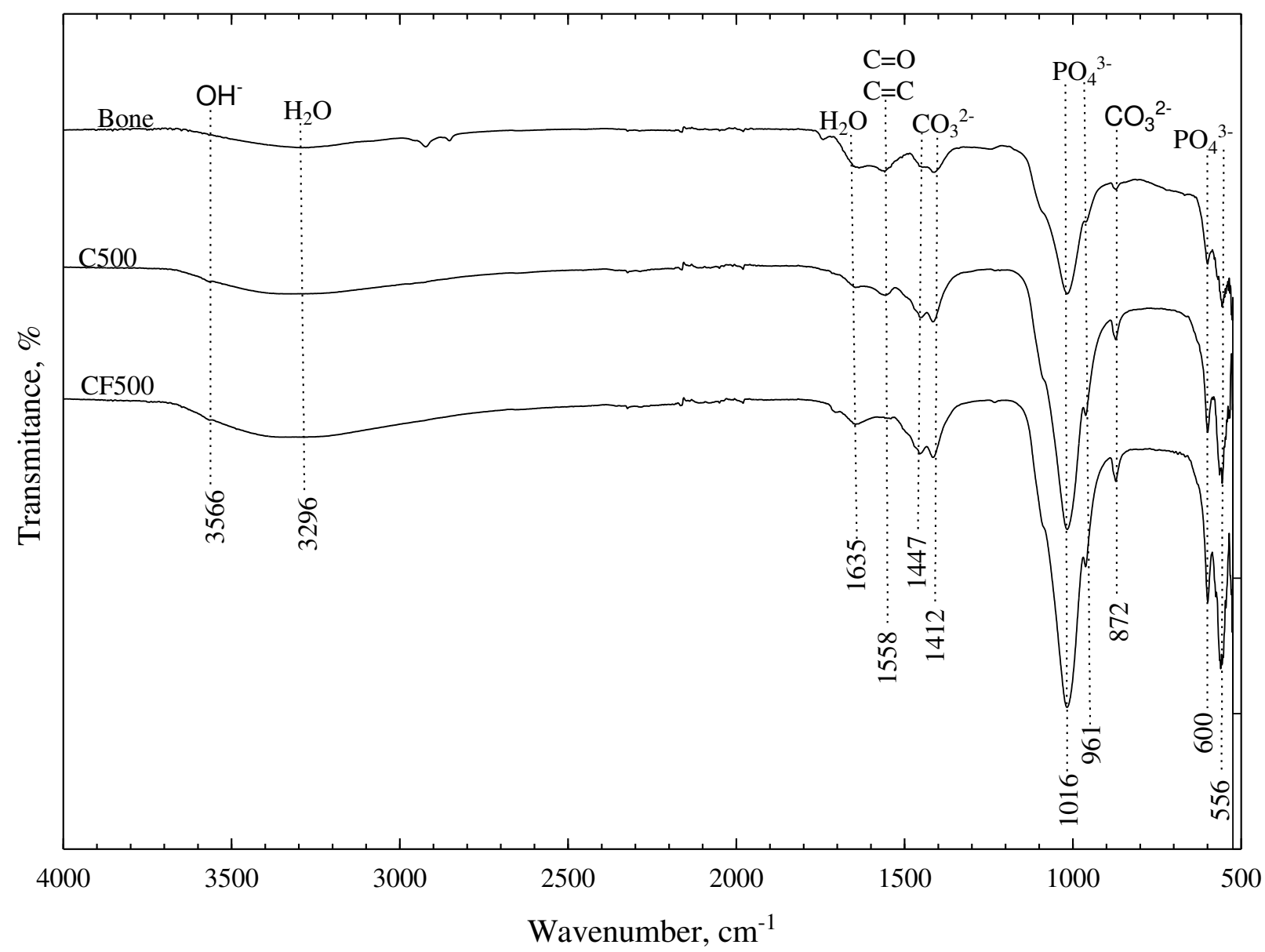

290

Fig. 6. FT-IR spectra of Bone, C500 and CF500.

Fig. 8 shows the diffractograms of Bone, C500 and CF500, and the peaks identified in all the samples correspond to hydroxyapatite, $\mathrm{Ca}_{10}\left(\mathrm{PO}_{4}\right)_{6}(\mathrm{OH})_{2}$. The characteristic maximum peaks of hydroxyapatite are found in the values of $25.9^{\circ}, 31.7^{\circ}, 46.7^{\circ}$ and $49.5^{\circ}$ on $2 \theta$ and are consistent with those reported by some authors (Bedin et al. 2017; Medellin-Castillo et al. 2020). Similarly, the peaks of hydroxyapatite observed in sample Bone increase when pyrolysed, indicating that the percentage of hydroxyapatite increases, and these peaks present a decrease in the CF500 sample indicating a saturation of fluoride on the hydroxyapatite. 


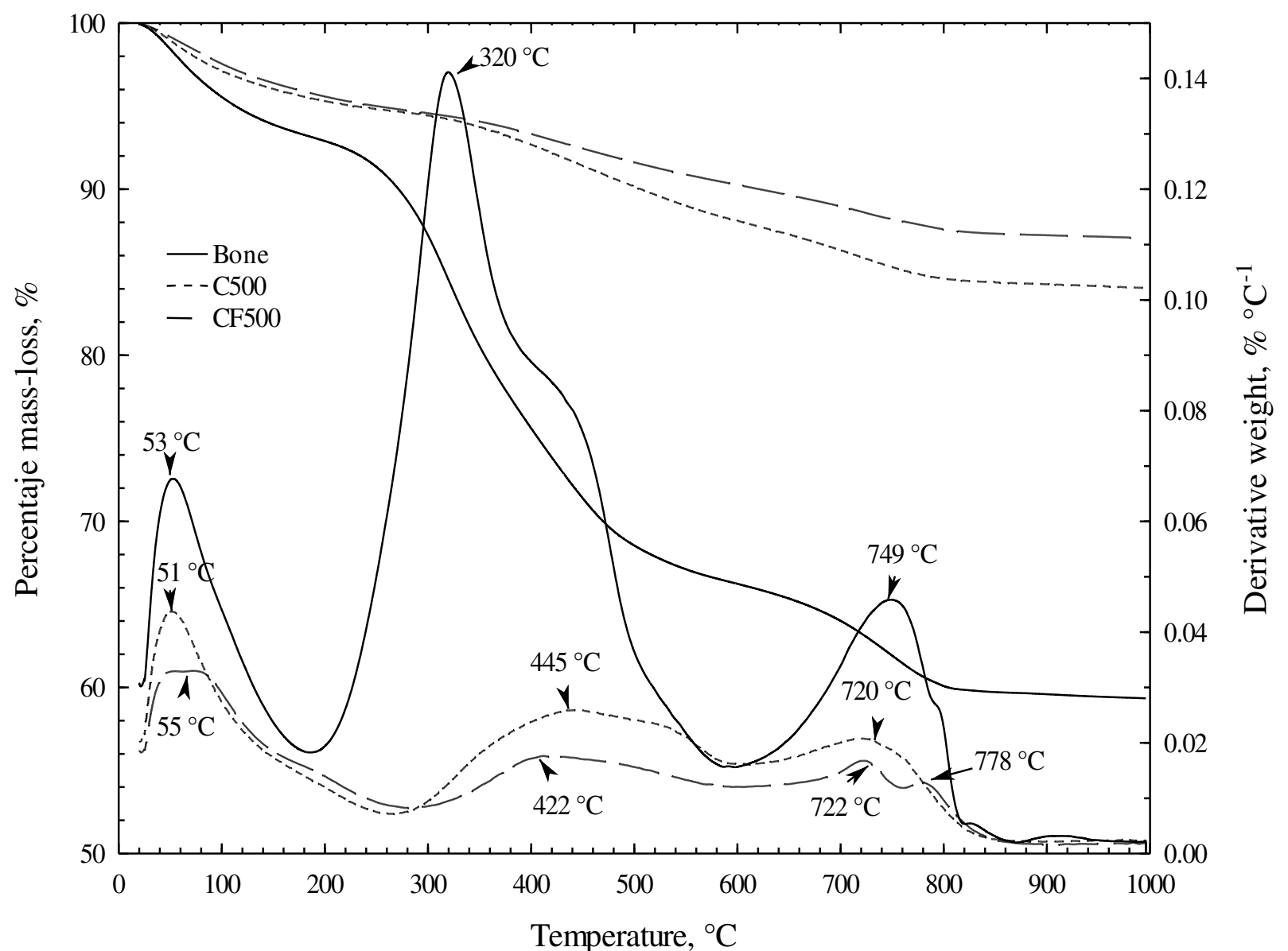

Fig. 7. TGA samples of Bone, C500 and CF500. 


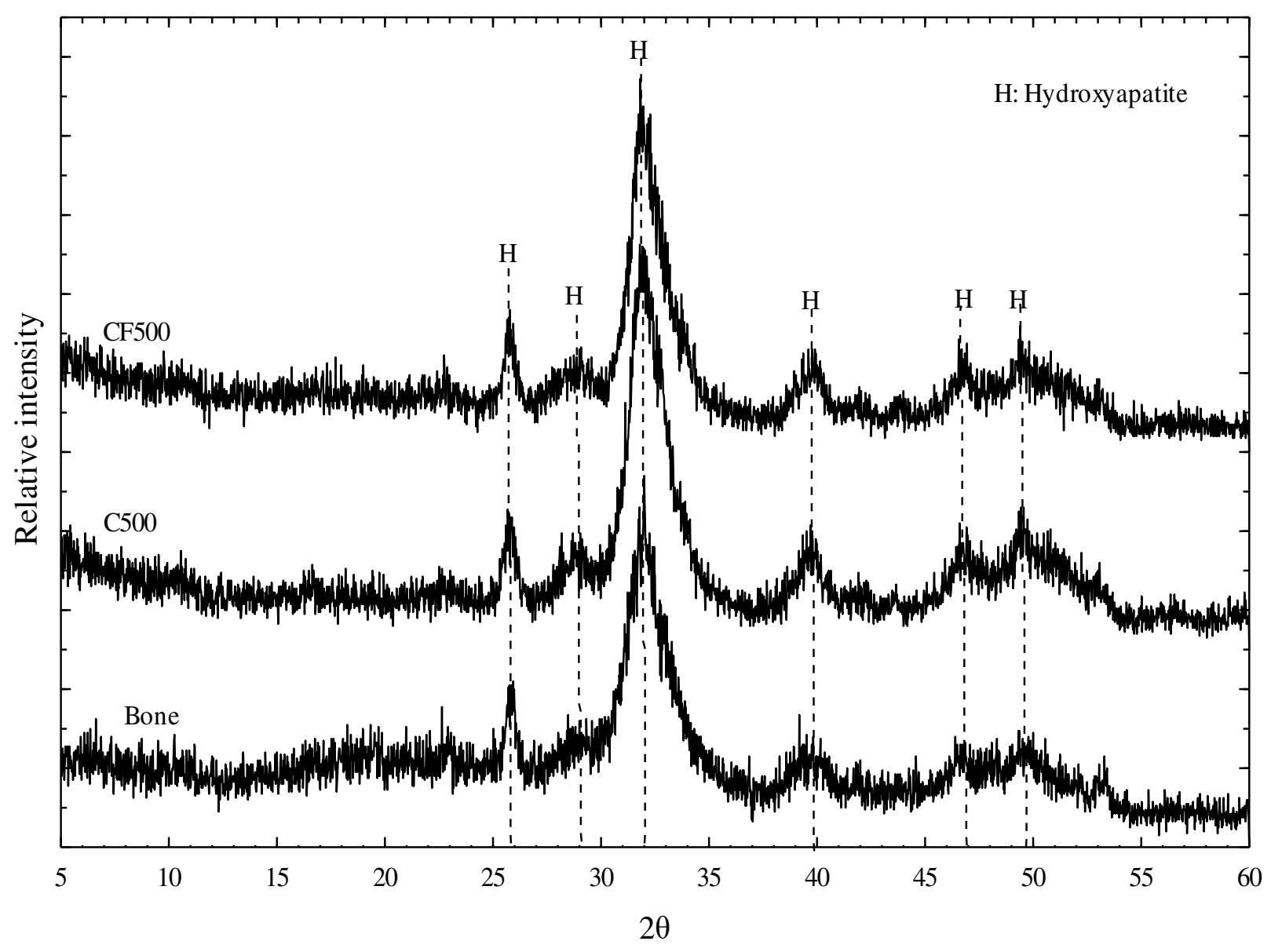

Fig. 8. XRD patterns of Bone, C500 and CF500.

\subsection{Adsorption isotherms}

306 The experimental data of the fluoride adsorption on bone char from devilfish were matched to

307 the Langmuir, Freundlich and Prausnitz-Radke adsorption isotherm models which are shown 308 in equations 5, 6 and 7, respectively.

$$
\mathrm{q}=\frac{\mathrm{q}_{\mathrm{m}} \mathrm{KC}_{\mathrm{e}}}{1+\mathrm{KC} \mathrm{e}_{\mathrm{e}}}
$$

$$
\mathrm{q}=\mathrm{kC}_{\mathrm{e}}^{1 / \mathrm{n}}
$$

$$
\mathrm{q}=\frac{\mathrm{aC}_{\mathrm{e}}}{1+\mathrm{bC}_{\mathrm{e}}^{\beta}}
$$


where $\mathrm{q}\left(\mathrm{mg} \mathrm{g}^{-1}\right)$ is the fluoride adsorption capacity, $\mathrm{C}_{\mathrm{e}}\left(\mathrm{mg} \mathrm{L}^{-1}\right)$ is the fluoride concentration at equilibrium. The Langmuir constants $K\left(\mathrm{~L} \mathrm{mg}^{-1}\right)$ and $\mathrm{q}_{\mathrm{m}}\left(\mathrm{mg} \mathrm{g}^{-1}\right)$ describe adsorption energy and maximum adsorption capacity, respectively; $k\left(\mathrm{mg}^{1-1 / n} \mathrm{~L}^{1 / n} \mathrm{~g}^{-1}\right)$ and $1 / \mathrm{n}$ are the Freundlich constants, and the parameters a $\left(\mathrm{L} \mathrm{g}^{-1}\right), \mathrm{b}\left(\mathrm{L} \mathrm{mg}^{-1}\right)^{\beta}$ and $\beta$ are the Prausnitz-Radke constants.

The constants of these isotherms were evaluated using a method of least squares based on the Rosenbrock-Newton optimisation algorithm and using a criterion of minimum percentage standard deviation, which is defined as

$$
\% \mathrm{D}=\left|\frac{\mathrm{q}_{\mathrm{exp}}-\mathrm{q}_{\mathrm{cal}}}{\mathrm{q}_{\exp }}\right| \times 100
$$

where $\mathrm{q}_{\exp }\left(\mathrm{mg} \mathrm{g}^{-1}\right)$ is the experimental amount of adsorbed fluoride and $\mathrm{q}_{\mathrm{cal}}\left(\mathrm{mg} \mathrm{g}^{-1}\right)$ is the amount of adsorbed fluoride predicted.

The isotherm constant values and their $\% \mathrm{D}$ for the fluoride adsorption equilibrium on C500 are shown in Table 3. As it can be seen, the experimental data were better interpreted by threeparameter isotherm model, as the \%D were less than $8.70,11.37$ and $19.84 \%$ for the PrausnitzRadke, Langmuir and Freundlich isotherms, respectively.

Table 3. Isotherms parameters for the fluoride adsorption on $\mathrm{C} 500$ at $\mathrm{T}=25^{\circ} \mathrm{C}$.

\begin{tabular}{|c|c|c|c|c|c|c|c|c|c|c|c|}
\hline \multirow[b]{2}{*}{$\begin{array}{c}\mathrm{T} \\
\left({ }^{\circ} \mathrm{C}\right)\end{array}$} & \multirow[b]{2}{*}{$\mathrm{pH}$} & \multicolumn{3}{|c|}{ Langmuir } & \multicolumn{3}{|c|}{ Freundlich } & \multicolumn{4}{|c|}{ Prausnitz-Radke } \\
\hline & & $\begin{array}{c}\mathrm{q}_{\mathrm{m}} \\
\left(\mathrm{mg} \mathrm{L}^{-1}\right)\end{array}$ & $\begin{array}{c}\mathrm{K} \\
\left(\mathrm{L} \mathrm{mg}^{-1}\right)\end{array}$ & $\% \mathrm{D}$ & $\begin{array}{c}\mathrm{k} \\
\left(\mathrm{mg}^{1-1 / n}\right. \\
\left.\mathrm{L}^{1 / 1 / n} \mathrm{mg}^{-1}\right)\end{array}$ & $1 / \mathrm{n}$ & $\% \mathrm{D}$ & $\begin{array}{c}\mathrm{a} \\
\left(\mathrm{L} \mathrm{g}^{-1}\right)\end{array}$ & $\begin{array}{c}\mathrm{b} \\
\left(\mathrm{L} \mathrm{mg}^{-1}\right)^{\beta}\end{array}$ & $\beta$ & $\% \mathrm{D}$ \\
\hline 15 & 7 & 12.1 & 0.65 & 11.2 & 4.31 & 3.15 & 9.67 & 14.5 & 1.95 & 0.85 & 4.34 \\
\hline \multirow[t]{3}{*}{25} & 5 & 22.6 & 1.44 & 8.83 & 9.71 & 2.74 & 19.8 & 33.1 & 1.49 & 0.99 & 8.70 \\
\hline & 7 & 12.7 & 0.73 & 4.30 & 4.65 & 3.21 & 8.95 & 12.5 & 1.31 & 0.91 & 0.88 \\
\hline & 9 & 9.99 & 0.16 & 10.7 & 2.08 & 2.44 & 3.36 & 18.1 & 7.74 & 0.62 & 2.69 \\
\hline 35 & 7 & 15.2 & 0.79 & 11.4 & 5.58 & 3.06 & 8.11 & 23.9 & 2.62 & 0.83 & 2.36 \\
\hline
\end{tabular}


3.6 Adsorption capacity and its effect by the solution $\mathrm{pH}$

The fluoride adsorption on $\mathrm{C} 500$ was studied at $25^{\circ} \mathrm{C}$ and at different solution pH (5.0, 7.0 and 9.0) to evaluate its effect on the adsorption capacity, the results are shown in Fig. 9, a higher amount of fluoride adsorbed from the aqueous solutions at $\mathrm{pH}=5.0$, compared to the higher $\mathrm{pH}$ values show that the adsorption capacity of the C500 sample was significantly dependent on the $\mathrm{pH}$. This behavior coincides with that reported by other authors, who also studied the adsorption of fluorides in bone char (Medellin-Castillo et al. 2020; Zúñiga-Muro et al. 2017).

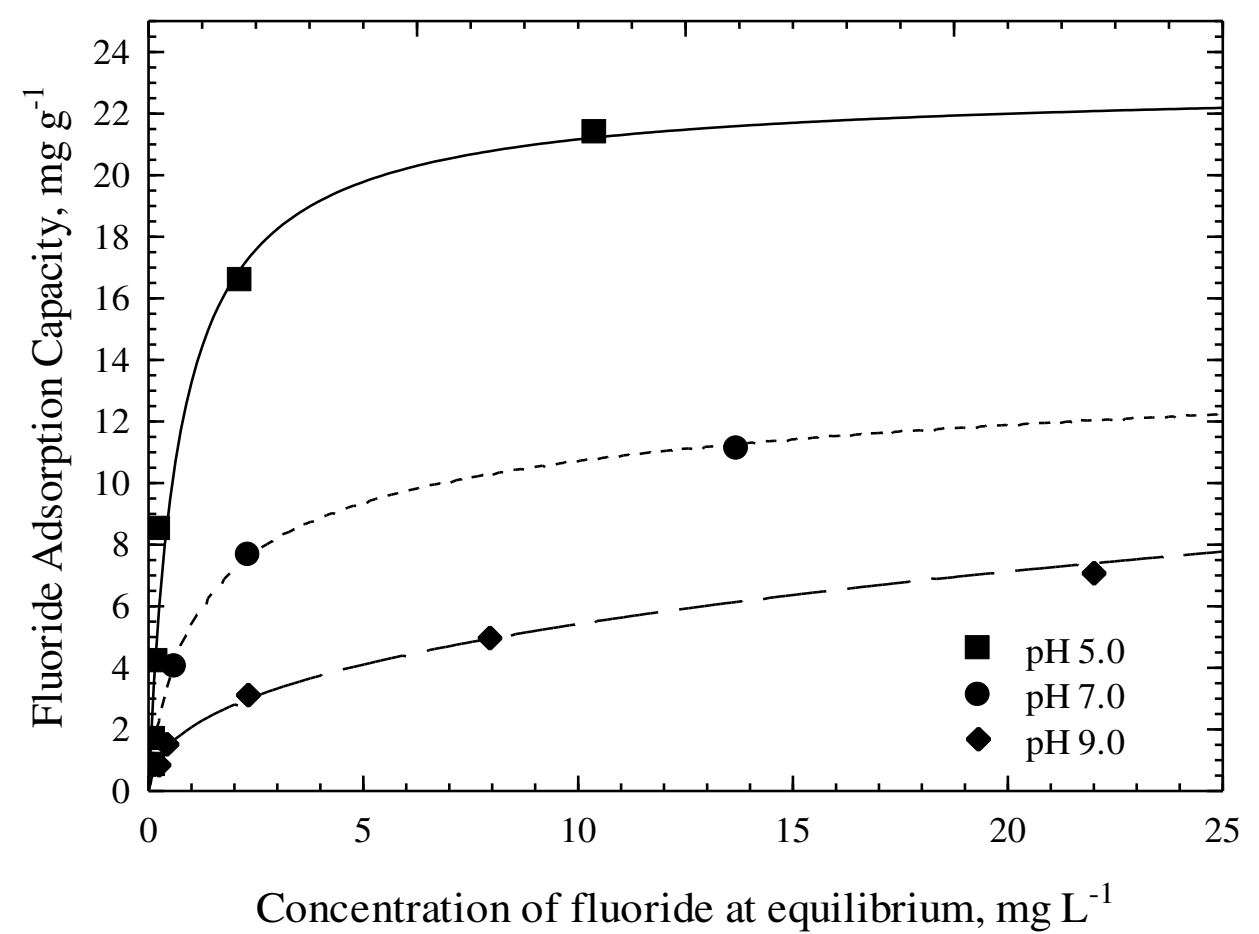

Fig. 9. Effect of solution $\mathrm{pH}$ on the fluoride adsorption capacity on $\mathrm{C} 500$ at $\mathrm{T}=25^{\circ} \mathrm{C}$.

Electrostatic interactions may explain the effect of solution $\mathrm{pH}$. Considering that the $\mathrm{pH}$ PZC of C500 is 6.93 (Table 2), this implies that the surface of the bone char is positively charged at solution $\mathrm{pH}$ below the $\mathrm{pH}$ PZC. Under these conditions, the electrostatic interaction between the fluoride ions in solution and the positive surface of the C500 is the main mechanism of fluorine adsorption. Therefore, at solution $\mathrm{pH}$ below their respective $\mathrm{pH}_{\mathrm{PZC}}$, electrostatic attraction 
favors fluoride adsorption. The positive charge of the surface increases by lowering the $\mathrm{pH}$ below the pHPZC (Nigri et al. 2019).

In addition, as shown in XRD analysis, the main constituent of bone char is hydroxyapatite, so the groups on the surface of solid that affect its surface charge are phosphates, $\equiv \mathrm{P}-\mathrm{OH}$, and hydroxyl, $\equiv \mathrm{Ca}-\mathrm{OH}$, this groups can interact with the solvent and the ions in aqueous solution (Nigri et al. 2019).

\subsection{Effect of solution temperature and thermodynamic properties}

Fig. 10 presents the effect of temperature on the fluoride adsorption capacity of the C500 sample at 15,25 and $35{ }^{\circ} \mathrm{C}$ at $\mathrm{pH}$ 7. The results obtained show that temperature influences the adsorption capacity, because at a temperature of $35^{\circ} \mathrm{C}$ a larger amount of fluoride is adsorbed. Therefore, when the solution temperature is increased, fluoride ions have more energy and therefore more fluoride ions can be adsorbed on the surface of the bone char as they have enough energy (Cooney 1998).

The isosteric heat of adsorption was evaluated in order to determine this thermodynamic parameter that explains the nature of adsorption and relates it to the heat of adsorption. The isosteric heat was evaluated according to the equation:

$$
\left(\Delta \mathrm{H}_{\mathrm{ads}}\right)_{\mathrm{q}}=\frac{\mathrm{R} \ln \frac{\mathrm{C}_{2}}{\mathrm{C}_{1}}}{\frac{1}{\mathrm{~T}_{2}-\frac{1}{\mathrm{~T}_{1}}}}
$$

where $\left(\Delta \mathrm{H}_{\mathrm{ads}}\right)_{\mathrm{q}}$ represents the isosteric heat of adsorption $\left(\mathrm{J} \mathrm{mol}^{-1}\right), \mathrm{R}$ is the universal constant of the ideal gases $\left(\mathrm{J} \mathrm{mol}^{-1} \mathrm{~K}^{-1}\right), \mathrm{C}_{1}$ and $\mathrm{C}_{2}\left(\mathrm{mg} \mathrm{L}^{-1}\right)$ are the fluoride concentrations at $\mathrm{T}_{1}$ and $\mathrm{T}_{2}$, respectively, at the same value of $\mathrm{q}$ and $\mathrm{T}_{1}$ and $\mathrm{T}_{2}(\mathrm{~K})$ are the temperatures at conditions 1 and 2. 
At a mass of fluoride adsorbed on C500 of q=7.0 $\mathrm{mg} \mathrm{g}^{-1}$ the equilibrium fluoride concentrations were $\mathrm{C}_{1}=2.624 \mathrm{mg} \mathrm{L}^{-1}$ and $\mathrm{C}_{2}=1.163 \mathrm{mg} \mathrm{L}^{-1}$, at temperatures $\mathrm{T}_{1}=288.15 \mathrm{~K}_{\text {and }} \mathrm{T}_{2}=308.15 \mathrm{~K}$, respectively. The isosteric heat calculated was $30.038 \mathrm{~kJ} \mathrm{~mol}^{-1}$. This indicates that fluoride adsorption on $\mathrm{C} 500$ is an endothermic and physical process $\left(<83 \mathrm{~kJ} \mathrm{~mol}^{-1}\right)$.

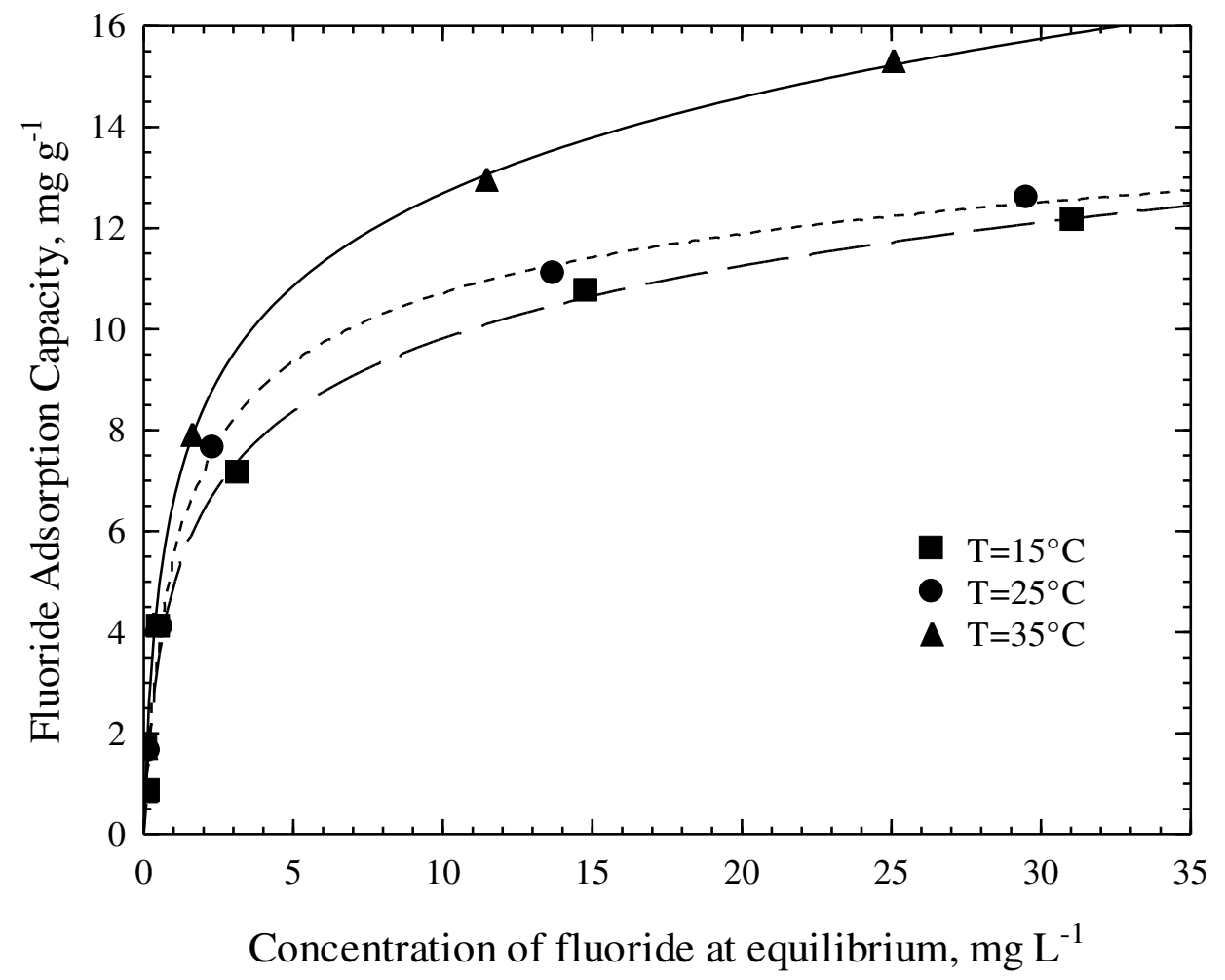

Fig. 10. Effect of solution temperature on the fluoride adsorption capacity of $\mathrm{C} 500$ at $\mathrm{pH}=7.0$

The Gibbs free energy $\left(\Delta \mathrm{G}^{\circ}\right)$, enthalpy $\left(\Delta \mathrm{H}^{\circ}\right)$ and entropy $\left(\Delta \mathrm{S}^{\circ}\right)$ of the fluoride adsorption process on devilfish bone char was determined through the following equations using the value of the Langmuir constant $\mathrm{K}$ at different conditions reported in Table 4:

$$
\Delta \mathrm{G}^{\mathrm{o}}=-\mathrm{RT} \ln \mathrm{K}
$$

$$
\ln \mathrm{K}=-\frac{\Delta \mathrm{G}^{\mathrm{o}}}{\mathrm{RT}}=-\frac{\Delta \mathrm{H}^{\mathrm{o}}}{\mathrm{RT}}+\frac{\Delta \mathrm{S}^{\mathrm{o}}}{\mathrm{R}}
$$

378 The thermodynamic parameters evaluated for the fluoride adsorption process on bone char are shown in Table 4. The estimation of the isosteric heat of adsorption revealed that the fluoride 
adsorption is endothermic. The positive $\Delta \mathrm{H}^{\circ}$ values estimated corroborate the endothermic nature of fluoride adsorption. Positive $\Delta \mathrm{S}^{\circ}$ values show the affinity of fluoride to devilfish bone char.

Table 4. Thermodynamic parameters estimated for adsorption of fluoride on C500 from devilfish.

\begin{tabular}{|c|c|c|c|c|c|c|}
\hline Sample & $\begin{array}{c}\mathbf{T} \\
\left({ }^{\circ} \mathbf{C}\right)\end{array}$ & $\begin{array}{c}\mathrm{K} \\
\left(\mathrm{L} \mathrm{mg}^{-1}\right)\end{array}$ & $\begin{array}{c}\mathbf{K} \times 10^{-3} \\
\left(\mathbf{L} \mathbf{~ m o l}^{-\mathbf{1}}\right)\end{array}$ & 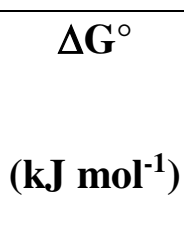 & $\begin{array}{c}\Delta \mathrm{H}^{\circ} \\
\left(\mathbf{k J ~ \mathrm { mol } ^ { - 1 }}\right)\end{array}$ & $\begin{array}{c}\Delta \mathbf{S}^{\circ} \\
\left(\mathrm{J} \mathrm{mol}^{-1} \mathbf{K}^{-1}\right)\end{array}$ \\
\hline \multirow{3}{*}{ C500 } & 15 & 0.65 & 12.35 & -22.57 & \multirow{3}{*}{7.213} & \multirow{3}{*}{103.4} \\
\hline & 25 & 0.73 & 13.87 & -23.64 & & \\
\hline & 35 & 0.79 & 15.01 & -24.64 & & \\
\hline
\end{tabular}

\subsection{Reversibility of the fluoride adsorption process and thermal regeneration}

The experimental data of the desorption of the adsorbed fluoride on C500 are shown in Fig. 11 and were obtained by first adsorbing the fluoride on $\mathrm{C} 500$ at $\mathrm{pH} 5.0$ and $\mathrm{T}=25{ }^{\circ} \mathrm{C}$, and then desorbing the adsorbed fluoride using a non-fluoride solution at $\mathrm{pH} 5.0$ and 9.0 and $\mathrm{T}=25{ }^{\circ} \mathrm{C}$, until a new equilibrium was reached.

In Fig. 11, it can be observed that fluoride is very slightly desorbed from $\mathrm{C} 500$ at $\mathrm{pH}$ 5.0. The fluoride desorbed from C500 increases as the $\mathrm{pH}$ of the solution increases. Therefore, the desorption of fluoride ions at high $\mathrm{pH}$ values is related to the repulsive forces between negative charged surface groups due to the deprotonation and the negatively charged fluoride ions in solution as well as the competition between $\mathrm{OH}^{-}$from the solution and fluoride ions during the adsorption process. 


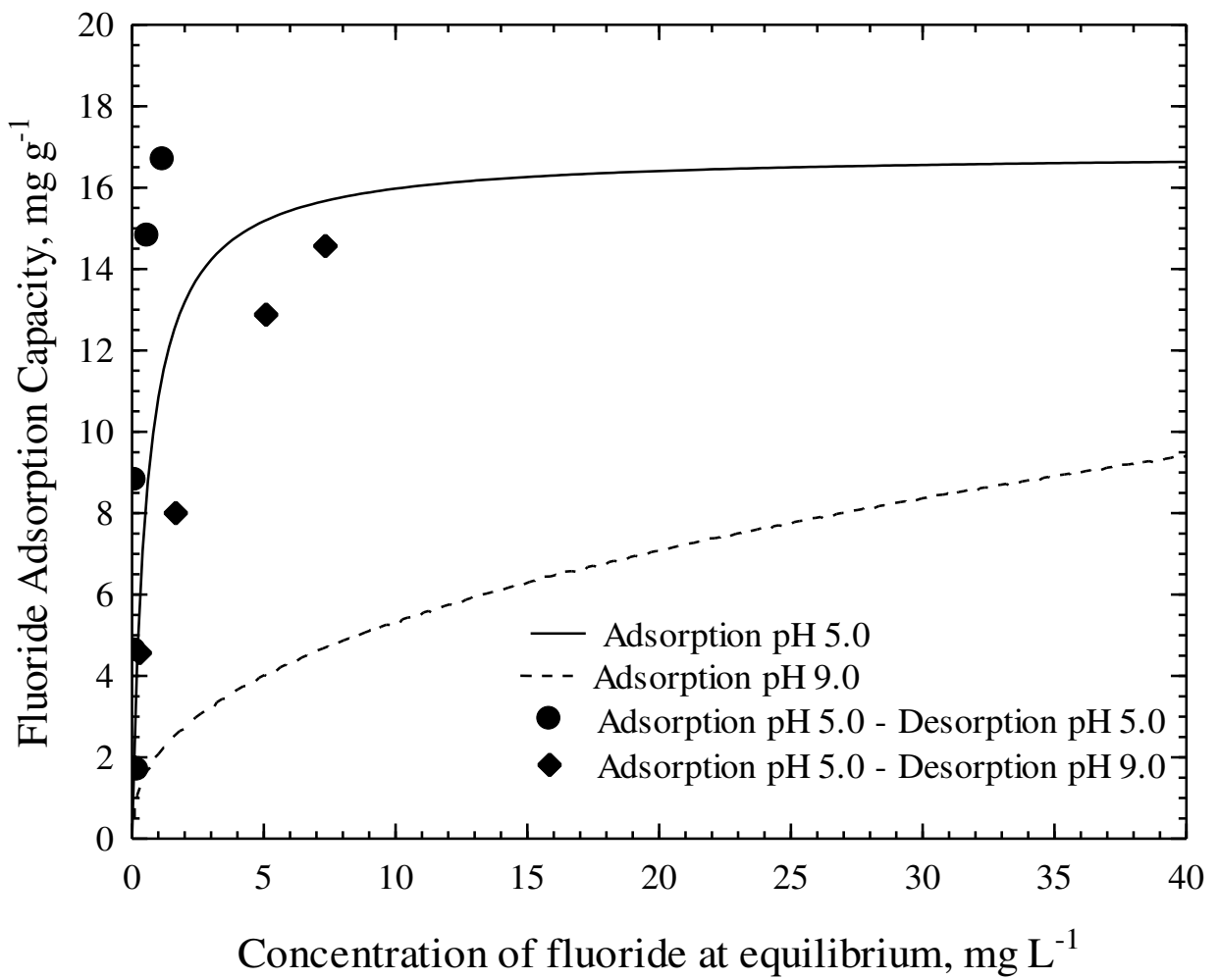

399 Fig. 11. Fluoride adsorption-desorption equilibrium on $\mathrm{C} 500$ at different values of $\mathrm{pH}$ and $\mathrm{T}=25^{\circ} \mathrm{C}$.

401

This reveals that fluoride is desorbed to a greater extent from $\mathrm{C} 500$ at more basic solution $\mathrm{pH}$. That is, the desorption at $\mathrm{pH} 5.0$ shows us that the fluoride that is desorbed goes from 0.24 to $3.06 \%$, while for desorption at $\mathrm{pH} 9.0$ it goes from 1.03 to $20.06 \%$, this indicates that the fluoride desorption process in $\mathrm{C} 500$ at both pHs is partially reversible, therefore the adsorption is not completely physical, there is also the adsorption by chemisorption or by ion exchange. The adsorption capacities of the regenerated materials as well as the $\mathrm{C} 500$ before regeneration are shown in Figure 12. The results show that the fluoride adsorption capacities are maintained 409 after thermal regeneration as the adsorption capacities vary slightly compared to C500 and show a similar variation to the study of the effect of the pyrolysis temperature of bone char. 


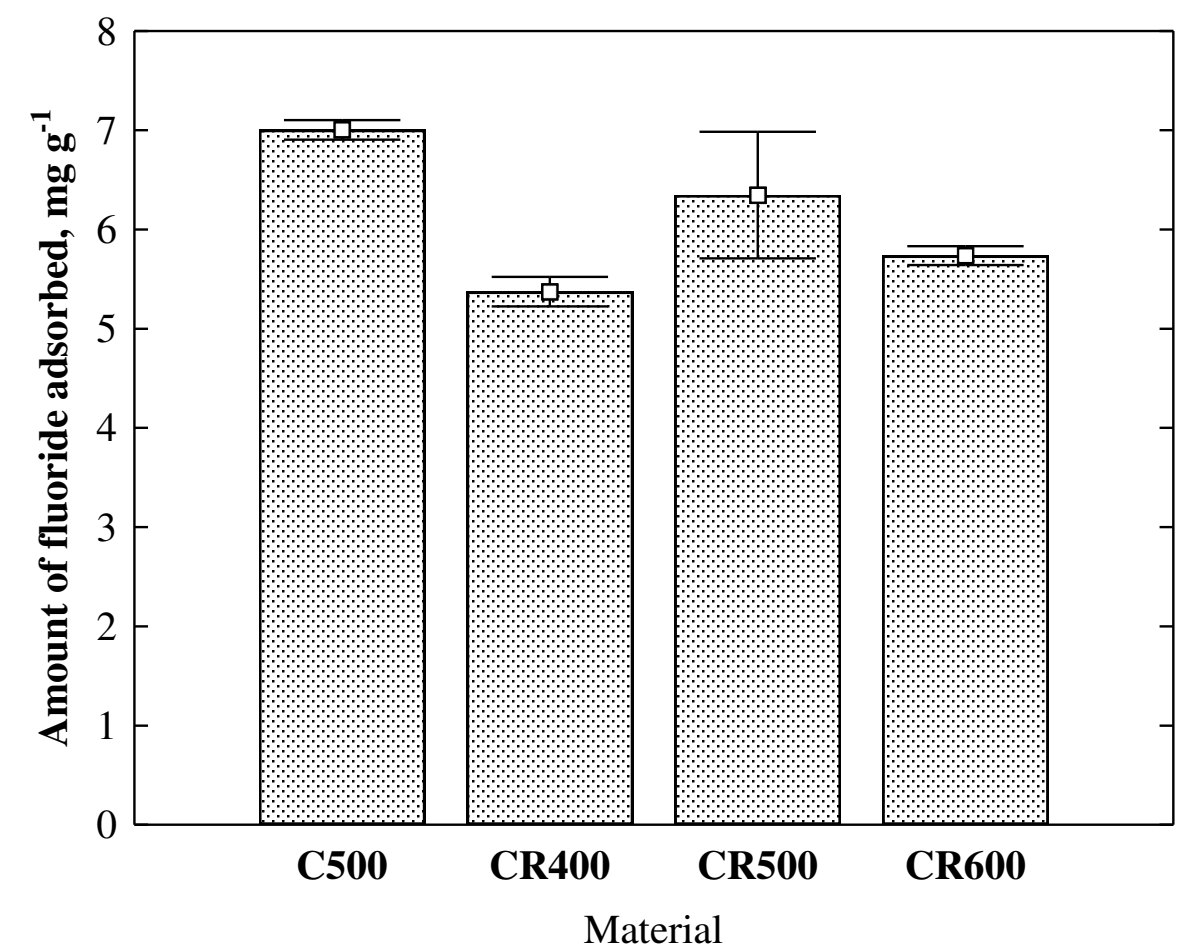

Fig. 12. Fluoride adsorption capacities of bone char thermally regenerated.

3.9 Removal of fluoride from drinking well water in a rural community

415 La Laborcilla rural community has a population of approximately 781 inhabitants whose main economic activities are agriculture, livestock and masonry. This community is supplied with water from a well with an approximate depth of $400 \mathrm{~m}$. Physical-chemical parameters of the drinking water are shown in Table 5. The water is used for human consumption and in all economic activities of the community. In addition, the elementary school Aquiles Serdan is located in this community and it has a registration of 120 students between the ages of 6 and 12 who drink water from water dispenser that are supplied by the well mater. For this reason, it is common to observe the presence of dental fluorosis among the students and inhabitants of this 423 area. Fig. 2 shows some photos of the location of the community, well, water dispensers and 424 dental fluorosis in a child. This type of problem is common in the Altiplano and Central areas 425 of San Luis Potosi, Mexico, as also in other central and northern states of Mexico (Ledon et al. 426 2018; Otazo-Sánchez et al. 2020). Fluorosis is a serious health problem worldwide and it has 
been reported that more than 35 countries have excess fluoride in their drinking water (Alkurdi et al. 2019).

Table 5. Parameters of the drinking water from the rural community La Laborcilla, Villa de Arriaga, Mexico

\begin{tabular}{|c|c|c|c|}
\hline \multirow[t]{2}{*}{ Parameter } & \multirow{2}{*}{$\begin{array}{c}\text { Concentration } \\
\text { determined }\end{array}$} & \multicolumn{2}{|c|}{ Permissible limits } \\
\hline & & NOM & WHO \\
\hline $\mathrm{pH}$ & 7.88 & $6.5-8.5$ & NVP \\
\hline Colour $(\mathrm{Co} / \mathrm{Pt})$ & 0.00 & 20.0 & Colourless \\
\hline Odour & Odourless & Odourless & Odourless \\
\hline Turbidity (NTU) & 0.50 & 10.0 & $<0.2$ \\
\hline Total hardness $\left(\mathrm{mg} \mathrm{CaCO}_{3} / \mathrm{L}\right)$ & 122 & 500 & NVP \\
\hline $\mathrm{Ca}$ hardness $\left(\mathrm{mg} \mathrm{CaCO}_{3} / \mathrm{L}\right)$ & 95.0 & NVP & NVP \\
\hline $\mathrm{Mg}$ hardness $\left(\mathrm{mg} \mathrm{CaCO}_{3} / \mathrm{L}\right)$ & 27.0 & NVP & NVP \\
\hline Chlorides (mg/L) & 45.0 & 250 & NVP \\
\hline Fluorides (mg/L) & 4.50 & 1.50 & 1.50 \\
\hline Nitrites (mg/L) & Absent & 1.00 & 3.00 \\
\hline Nitrates $(\mathrm{mg} / \mathrm{L})$ & 9.30 & 10.0 & 50.0 \\
\hline Sulfates $(\mathrm{mg} / \mathrm{L})$ & 45.0 & 400 & NVP \\
\hline $\begin{array}{c}\text { Mesophilic Aerobic } \\
\text { Microorganisms (UFC/mL) }\end{array}$ & 3904 & NVP & NVP \\
\hline Total coliforms (NMP/100 mL) & Absent & Absent & Absent \\
\hline Faecal coliforms (NMP/100 mL) & Absent & Absent & Absent \\
\hline Total dissolved solids (mg/L) & 376 & 1000 & NVP \\
\hline Chlorine (mg/L) & Absent & $0.10-1.50$ & 5.00 \\
\hline
\end{tabular}

NVP: No value proposed

433 Fluoride adsorption test were performed by contacting various masses (from 0.05 to $0.8 \mathrm{~g}$ ) of C500 sample with $100 \mathrm{~mL}$ of water of $\mathrm{pH}=7.88$ and according to the methodology mentioned 435 in section 2.6. Table 5 shows the parameters determined for water, as well as the maximum 436 permissible limit for each parameter measured according to the Official Mexican Standards 
(NOM) and the Guidelines for Drinking-water Quality by World Health Organization (WHO

2017) and it can be noted that the only parameter of the water collected in the community of La

Laborcilla that is above the maximum permissible limit set by the Mexican Official Standards and the values suggested by the WHO are fluorides whose concentration is $4.5 \mathrm{mg} / \mathrm{L}, 3$ times

441 higher than the permitted concentration $\left(1.5 \mathrm{mg} \mathrm{L}^{-1}\right)$.

442 Table 6 shows that the \% of fluoride removal increases from 69.1 to $98.7 \%$ as the dose of C500

443 increases from 0.05 to $0.8 \mathrm{~g}$, until almost all the fluoride is removed from the water.

444 The increase in adsorption with the amount of the adsorbent may be due to a higher specific

445 surface area and concentration of adsorption sites.

446 Table 6. Removal of fluorides and other anions in drinking water using $\mathrm{C} 500$ at $\mathrm{T}=25^{\circ} \mathrm{C}$ and 447 without $\mathrm{pH}$ control.

448

\begin{tabular}{|c|c|c|c|c|c|c|c|c|c|c|c|c|c|c|}
\hline \multirow{2}{*}{$\operatorname{Exp}$} & \multirow{2}{*}{$\begin{array}{l}\mathbf{m} \\
(\mathrm{g})\end{array}$} & \multicolumn{4}{|c|}{ Fluoride } & \multicolumn{3}{|c|}{$\begin{array}{l}\text { Total hardness } \\
\text { mg CaCO}_{3} \mathrm{~L}^{-1}\end{array}$} & \multicolumn{3}{|c|}{$\begin{array}{l}\text { Chloride } \\
\text { mg L }^{-1}\end{array}$} & \multicolumn{3}{|c|}{$\begin{array}{l}\text { Sulfate } \\
\mathrm{mg} \mathrm{L}^{-1}\end{array}$} \\
\hline & & $\begin{array}{c}\mathrm{C}_{0} \\
\left(\mathrm{mg} \mathrm{L}^{-1}\right)\end{array}$ & $\begin{array}{c}\mathrm{C}_{\mathrm{f}} \\
\left(\mathrm{mg} \mathrm{L}^{-1}\right)\end{array}$ & $\% \operatorname{Re}$ & $\begin{array}{c}\mathrm{q} \\
\left(\mathrm{mg} \mathrm{g}^{-1}\right)\end{array}$ & $\mathrm{C}_{0}$ & $\mathrm{C}_{\mathrm{f}}$ & $\% \operatorname{Re}$ & $\mathrm{C}_{0}$ & $\mathrm{C}_{\mathrm{f}}$ & $\% \operatorname{Re}$ & $\mathrm{C}_{0}$ & $\mathrm{C}_{\mathrm{f}}$ & $\% \operatorname{Re}$ \\
\hline 1 & 0.05 & 4.72 & 1.46 & 69.1 & 5.82 & 122 & 117.8 & 3.44 & 45.0 & 45.0 & 0.00 & 45.0 & 45.0 & 0.00 \\
\hline 2 & 0.1 & 4.72 & 0.56 & 88.1 & 3.74 & 122 & 113.8 & 6.72 & 45.0 & 45.0 & 0.00 & 45.0 & 40.5 & 10.0 \\
\hline 3 & 0.2 & 4.72 & 0.16 & 96.6 & 2.06 & 122 & 113.0 & 8.04 & 45.0 & 45.0 & 0.00 & 45.0 & 38.0 & 15.6 \\
\hline 4 & 0.4 & 4.72 & 0.10 & 97.9 & 1.04 & 122 & 111.0 & 9.02 & 45.0 & 45.0 & 0.00 & 45.0 & 35.0 & 22.2 \\
\hline 5 & 0.8 & 4.72 & 0.06 & 98.7 & 0.52 & 122 & 108.8 & 10.8 & 45.0 & 32.5 & 27.8 & 45.0 & 32.5 & 27.8 \\
\hline
\end{tabular}

449

450 On the other hand, the concentration of total hardness, chlorides and sulfates remain almost

451 constant, so it can be considered that these ions do not compete during the process of adsorption

452 of fluorides on C500.

453 Also, it was determined that the mass of C500 needed to reduce the concentration of fluoride

454 in water of the community of La Laborcilla, from 4.7 to $1.5 \mathrm{mg} \mathrm{L}^{-1}$, which is the maximum

455 permissible limit of the presence of fluoride in water for human use and consumption indicated

456 by the NOM-127-SSA1-1994, is $0.55 \mathrm{~g}$ of C500 for each L of water. 


\section{Conclusions}

The specific area, pore volume and pore diameter of the bone char prepared in this study are within the ranges of values reported in the literature for other bone char from other animals. $\mathrm{X}$-ray diffraction analysis determined that the species or crystalline phase in the bone char is hydroxyapatite $\left[\mathrm{Ca}_{10}\left(\mathrm{PO}_{4}\right)_{6}(\mathrm{OH})_{2}\right]$.

The study of the effect of the solution $\mathrm{pH}$ in the fluoride adsorption isotherm on $\mathrm{C} 500$ sample revealed that the adsorption capacity of this adsorbent to remove fluoride is considerably dependent on the solution $\mathrm{pH}$, as it increases with decreasing $\mathrm{pH}$. The study of the effect of temperature solution revealed that the adsorption on C500 is endothermic.

Fluoride can be desorbed from C500 but the adsorption equilibrium is not completely reversible as the $\%$ desorption varied of 0.24 to $20.06 \%$ indicating that fluoride adsorption occurs by physisorption and chemisorption mechanisms It was determined that fluoride-saturated bone carbonization can be thermally regenerated at $500{ }^{\circ} \mathrm{C}$ with a slight decrease in its adsorption capacity. The necessary mass of C500 to reduce the fluoride concentration of $4.7 \mathrm{mg} \mathrm{L}^{-1}$ in the drinking water of the community of La Laborcilla in the state of San Luis Potosi, to a concentration below $1.5 \mathrm{mg} \mathrm{L}^{-1}$ complying with the maximum permissible limit (NOM-127SSA1-1994), is $0.55 \mathrm{~g} \mathrm{~L}^{-1}$. The chemical composition of this water as also the characteristics of the well represent typical values for the central and northern zone of Mexico and other countries, whose results may be used for other studies. It was finally concluded that the adsorption of fluoride in aqueous solution on bone char from devilfish can be considered a viable and economic option in the treatment of water for human consumption.

\section{Declarations}

\section{Ethics approval and consent to participate}

Not applicable

\section{Consent for publication}


Not aplicable

Availability of data and materials

484

The datasets used and/or analysed during the current study are available from the corresponding

485 author on reasonable request.

486 Competing Interests

487 The authors declare that they have no competing interests

$488 \quad$ Funding

489 This study was supported by Consejo Nacional de Ciencias y Tecnología (CONACyT)

490 Project No. CB-2016-286990 and PN-2016-3947

491 Authors Contributions

492 Sergio Armando Cruz-Briano: Investigation, Methodology, Writing- Original Draft Nahum 493 Andrés Medellín-Castillo: Conceptualization, Methodology, Validation, Resources, Writing494 Original Draft, Writing- Review- Editing, Visualization, Supervision, Project Administration, 495 Funding acquisition Arturo Torres-Dosal: Investigation Roberto Leyva-Ramos: 496 Conceptualization, Validation, Resources, Writing- Review- Editing Juan Carlos Moreno497 Piraján: Validation, Writing- Review- Editing Liliana Giraldo-Gutiérrez: Validation César 498 Arturo Ilizaliturri-Hernandez: Investigation Paola Elizabeth Díaz-Flores: Methodology, 499 Writing- Review- Editing, Visualization Simón Yobanny Reyes- López: Resources, 500 Validation Raúl Ocampo-Pérez: Investigation, Writing-Review and Editing Jenny Paola 501 Rodríguez-Estupiñan: Investigation, Methodology Cristóbal Aldama-Aguilera: Resources, 502 Validation

503 


\section{Acknowledgments}

This work was supported by Consejo Nacional de Ciencia y Tecnología, CONACyT, Mexico, under grants Nos. CB-2016-286990 and PN- 2016-3947.

Dr. Gladis Judith Labrada Delgado for her contribution to the SEM analysis carried out at IPICyT

\section{References}

Abeykoon KGMD, Dunuweera SP, Liyanage DND, Rajapakse RMG (2020) Removal of fluoride from aqueous solution by porous Vaterite calcium carbonate nanoparticles. Mater Res Express 7(3). https://doi.org/10.1088/2053-1591/ab7692

Ahmad SZN, Hamdan R, Mohamed WAW, Othman N, Zin NSM (2018) Chemical composition, $\mathrm{pH}$ value, and points of zero charge of high calcium and high iron electric arc furnace slag. Int J Eng Technol (UAE), 7(3.23 Special Issue 23): 1-4.

Akafu T, Chimdi A, Gomoro K (2019) Removal of Fluoride from Drinking Water by Sorption Using Diatomite Modified with Aluminum Hydroxide. J Anal Methods Chem. https://doi.org/10.1155/2019/4831926

Alkurdi SSA, Al-Juboori RA, Bundschuh J, Hamawand I (2019) Bone char as a green sorbent for removing health threatening fluoride from drinking water. Environ Int 127(March): 704-719. https://doi.org/10.1016/j.envint.2019.03.065

Assaoui J, Hatim Z, Kheribeche A (2020) Synthesis and characterization of aluminum-based adsorbent and application in fluoride removal from aqueous solution. Mediterr $\mathrm{J}$ Chem 10(1):46. https://doi.org/10.13171/mjc101020291172ja

Bedin KC, de Azevedo SP, Leandro PKT, Cazetta AL, Almeida VC (2017) Bone char prepared by $\mathrm{CO}_{2}$ atmosphere: Preparation optimization and adsorption studies of Remazol Brilliant 
Bhatnagar A, Kumar E, Sillanpää M (2011) Fluoride removal from water by adsorption-A review. Chem Eng J 171(3):811-840. https://doi.org/10.1016/j.cej.2011.05.028

538

Bijukumar A, Smrithy R, Sureshkumar U, George S (2015) Invasion of South American suckermouth armoured catfishes Pterygoplichthys spp. (Loricariidae) in Kerala, India - a case study. J Threat Taxa 7(3):6987-6995. https://doi.org/10.11609/jott.o4133.6987-95

Cooney DO (1998). Adsorption Design for Wastewater Treatment. C. Press (ed.):2nd edn.

Emmanuel M, Wilson-Lamayi D, Shehu Z, Solomon-Kwarson P (2018). Equilibrium, isotherm and kinetic studies of flouride adsorption equilibrium, isotherm and kinetic studies of flouride adsorption on activated rice. Innovat International Journal of Medical \& Pharmaceutical Sciences.

Fan Z, Gao Y, Ning X, Pan F, Ming J (2019) Adsorption of Fluoride Ions from Water by SF/PP Nonwoven Fabrics. Fibers Polym 20(4):863-867. https://doi.org/10.1007/s12221-019$1085-0$

Figueiredo JL, Pereira MFR, Freitas MMA, Órfão JJM (1999) Modification of the surface chemistry of activated carbons. Carbon 37(9):1379-1389. https://doi.org/10.1016/S00086223(98)00333-9

Garcia-Gonzales A, Riveron-Giro F, Barba E (2017) Primer registro para Cuba del pez invasor Pterygoplichthys pardalis ( Siluriformes : Loricariidae ) First record of the invasive fish Pterygoplichthys pardalis. Rev Cuba Cien Biol 5:1-6.

García-Martínez M, Ramírez-Flores O, Ruiz-Olvera T, March-Mifsut I (2014) Especies invasoras acuáticas en áreas naturales protegidas. CONABIO 445-468.

Isaacs-Páez ED, Medellin-Castillo N, Manríquez-Guerrero F, Cercado B (2019) Characterization of Bone Char and Carbon Xerogel as Sustainable Alternative Bioelectrodes for Bioelectrochemical Systems. Waste Biomass Valorization. 

https://doi.org/10.1007/s12649-019-00817-4

Jalil SNA, Amri N, Ajien AA, Ismail NF, Ballinger B (2019) A hybrid electrocoagulationadsorption process for fluoride removal from semiconductor wastewater. J Phys Conf Ser 1349(1). https://doi.org/10.1088/1742-6596/1349/1/012056

Kaseva ME (2006) Contribution of trona (magadi) into excessive fluorosis-a case study in Maji ya Chai ward, northern Tanzania. Sci Total Environ 366(1):92-100. https://doi.org/10.1016/j.scitotenv.2005.08.049

Kini U, Nandeesh BN (2012) Physiology of Bone Formation, Remodeling, and Metabolism. Radionucl. Hybrid Bone Imaging 9783642024:1-1046. https://doi.org/10.1007/978-3642-02400-9

Kumar P, Prajapati AK, Dixit S, Yadav VL (2019) Adsorption of fluoride from aqueous solution using biochar prepared from waste peanut hull. Mater Res Express 6(12). https://doi.org/10.1088/2053-1591/ab6ca0

Ledon JM, Del Razo LM, Velasco MN (2018). Hacia el cumplimiento del Derecho Humano al Agua. Arsénico y fluoruro del agua: riesgos y perspectivas desde la Sociedad civil y la academia en México. In Secretaría de Gobernación, Comisión de Hábitat, Medio Ambiente y Sostenibilidad.

Maldonado EJ, López U, Salinas RM, González N, Cuenca C, Jiménez R, Hernández J (2015) Contenido de metales pesados en músculo de pez diablo Pterygoplichthys pardalis. Rev Iberoam Ciencias 2:67-73.

Medellin-Castillo NA, Cruz-Briano SA, Leyva-Ramos R, Moreno-Piraján JC, Torres-Dosal A, Giraldo-Gutiérrez L, Labrada-Delgado GJ, Pérez, RO, Rodriguez-Estupiñan JP, Reyes Lopez SY, Berber Mendoza MS (2020) Use of bone char prepared from an invasive species, pleco fish (Pterygoplichthys spp.), to remove fluoride and Cadmium(II) in water. J Environ Manage 256. https://doi.org/10.1016/j.jenvman.2019.109956 
Medellin-Castillo NA, Padilla-Ortega E, Tovar-García LD, Leyva-Ramos R, Ocampo-Pérez R, Carrasco-Marín F, Berber-Mendoza MS (2016) Removal of fluoride from aqueous solution using acid and thermally treated bone char. Adsorption 22(7):951-961. https://doi.org/10.1007/s10450-016-9802-0

Moncayo-Fernández A, Mejía-Egas O, Ramírez-Chaves HE (2017) Pterygoplichthys undecimalis (Siluriformes: Loricariidae): Una especie trasplantada en la cuenca del río Patía, Colombia.

Biota

Colomb 18(1):242-249. https://doi.org/10.21068/c2017.v18n01a15

Murillo YS, Giraldo L, Moreno JC (2012) Obtención de materiales porosos a partir de huesos de pollo y porcino para la adsorción de 2,4-dinitrofenol. Afinidad 68(556):447-452.

Nigri EM, Santos ALA, Bhatnagar A, Rocha SDF (2019) Chemical regeneration of bone char associated with a continuous system for defluoridation of water. Brazilian J Chem Eng 36(4):1631-1643. https://doi.org/10.1590/0104-6632.20190364s20180258

Otazo-Sánchez EM, Navarro-Frometá AE, Singh VP (2020) Water Availability and Management in Mexico. In Water Sci Technol Libr https://doi.org/10.1007/978-3-030$24962-5$

Purevsuren B, Davaajav Y, Namkhainorov J, Genadiev V (2017) Pyrolysis of animal bone, characterization of the obtained char and tar and application of bone tar for crosslinking of epoxy resin. Bulg Chem Commun 49(1):34-9.

Quintáns-Fondo A, Ferreira-Coelho G, Arias-Estévez M, Nóvoa-Muñoz JC, FernándezCalviño D, Álvarez-Rodríguez E, Fernández-Sanjurjo M, Núñez-Delgado A (2019). Chromium VI and Fluoride Competitive Adsorption on Different Soils and By-Products. Processes 1-13. https://doi.org/10.3390/pr7100748

Ríos-Muñoz CA (2015) Depredación de pez diablo (Loricariidae: Pterygoplichthys) por el cormorán oliváceo (Phalacrocorax brasilianus) en Villahermosa, Tabasco, México. Huitzil 
16(2):62-65. https://doi.org/10.28947/hrmo.2015.16.2.68

Rogers KD, Daniels P (2002) An X-ray diffraction study of the effects of heat treatment on bone mineral microstructure. Biomaterials 23(12): 2577-2585. https://doi.org/10.1016/S0142-9612(01)00395-7

Rosnaeni Elfidasari D, Fahmi M (2017) DNA Barcodes of the Pleco (Loricariidae, Pterygoplichthys) in the Ciliwung River. Int J Adv Res 5(2):33-45. https://doi.org/10.21474/ijar01/3113

Sandoval-Huerta ER, Madrigal-Guridi X, García-Meraz A, Dimas-Mora NI, DomínguezDomínguez O (2012) New record of Pterygoplichthys disjunctivus (Actinopterygii: Loricariidae) in the mouth of Coahuayana River, Coahuayana, Michoacán, Mexico. Rev Mex Biodivers 83(1):294-297.

Terasaka S, Kamitakahara M, Yokoi T, Ioku K (2014) Effect of preparation temperature on the ability of bone char to remove fluoride ion and organic contaminants. J Ceram Soc Japan 122(1432):995-999. https://doi.org/10.2109/jcersj2.122.995

Teusner A, Butler R, Le Clech P (2016) Impact of pretreatment on defluoridation of drinking water by bone char adsorption. J Humanit Eng 4(1):26-31. https://doi.org/10.36479/jhe.v4i1.48

Thomas AC, Tank S, Nguyen PL, Ponce J, Sinnesael M, Goldberg CS (2019) A system for rapid eDNA detection of aquatic invasive species. Environ DNA https://doi.org/10.1002/edn3.25

World Health Organization (WHO) (2017) Guidelines for drinking-water quality, 4th edition, incorporating the 1 st addendum.

Zúñiga-Muro NM, Bonilla-Petriciolet A, Mendoza-Castillo DI, Reynel-Ávila HE, TapiaPicazo JC (2017) Fluoride adsorption properties of cerium-containing bone char. J Fluor Chem 197:63-73. https://doi.org/10.1016/j.jfluchem.2017.03.004 
Figures

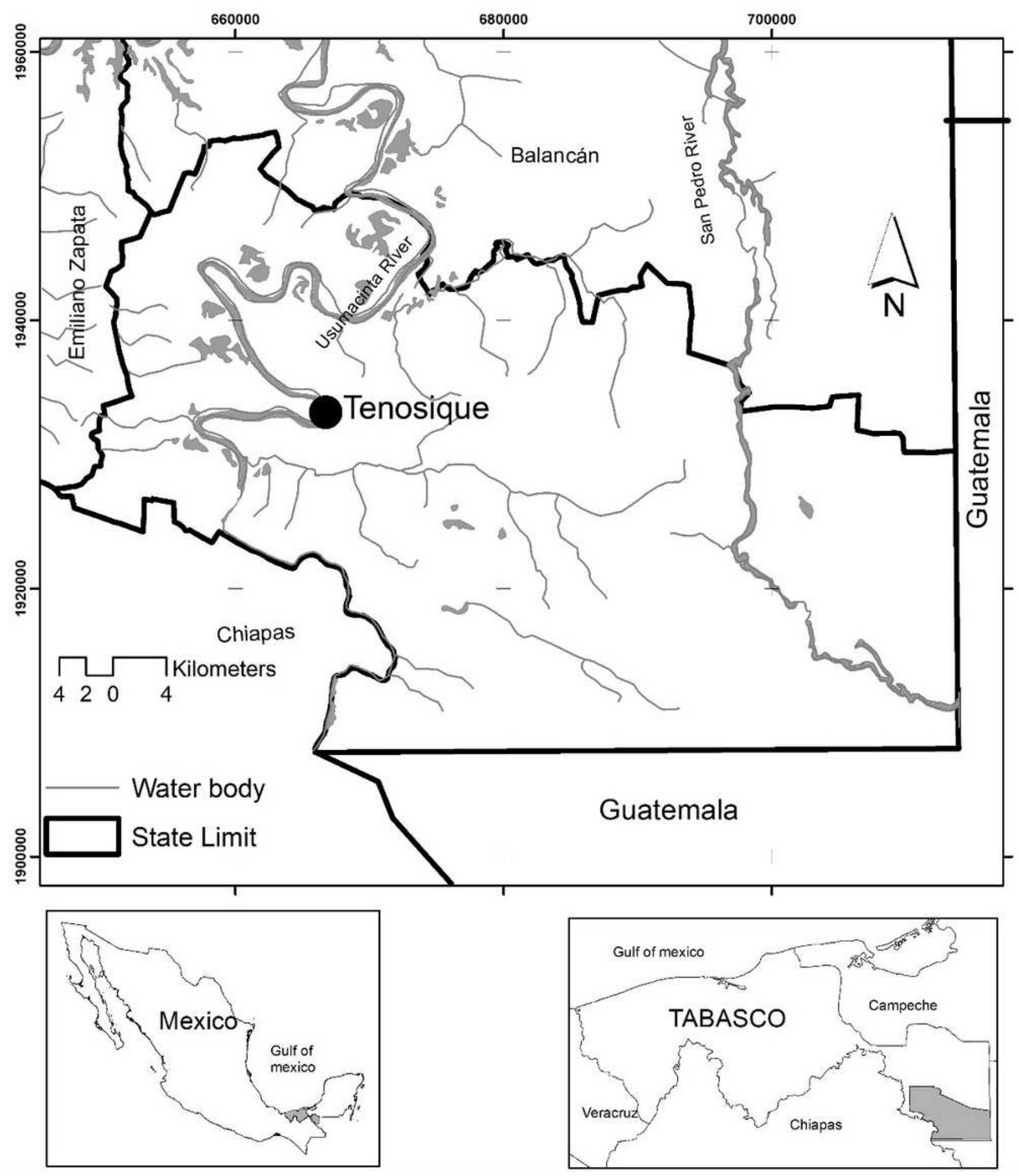

Figure 1

Location of the devilfish collection site. 

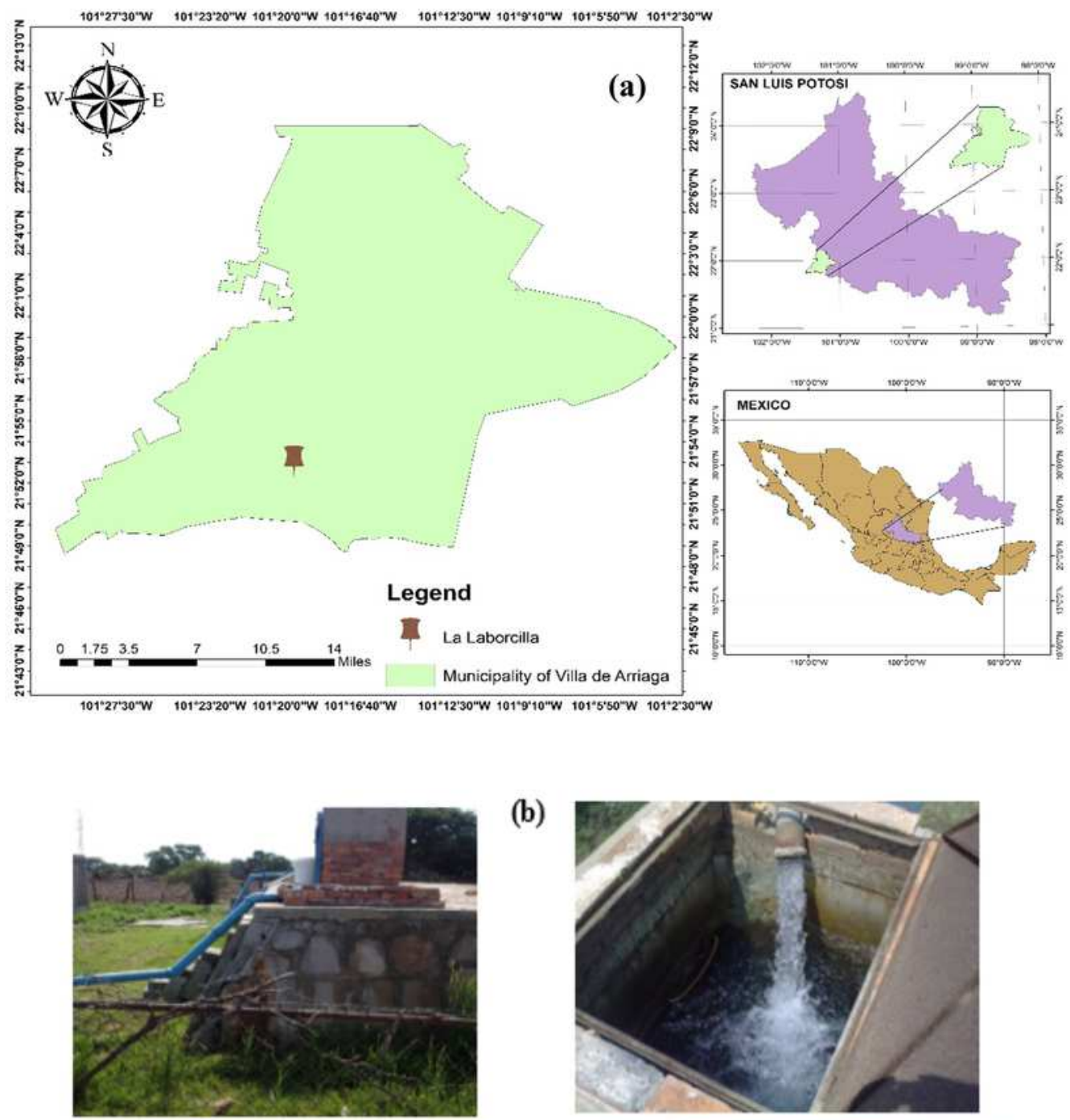

(b)

(c)
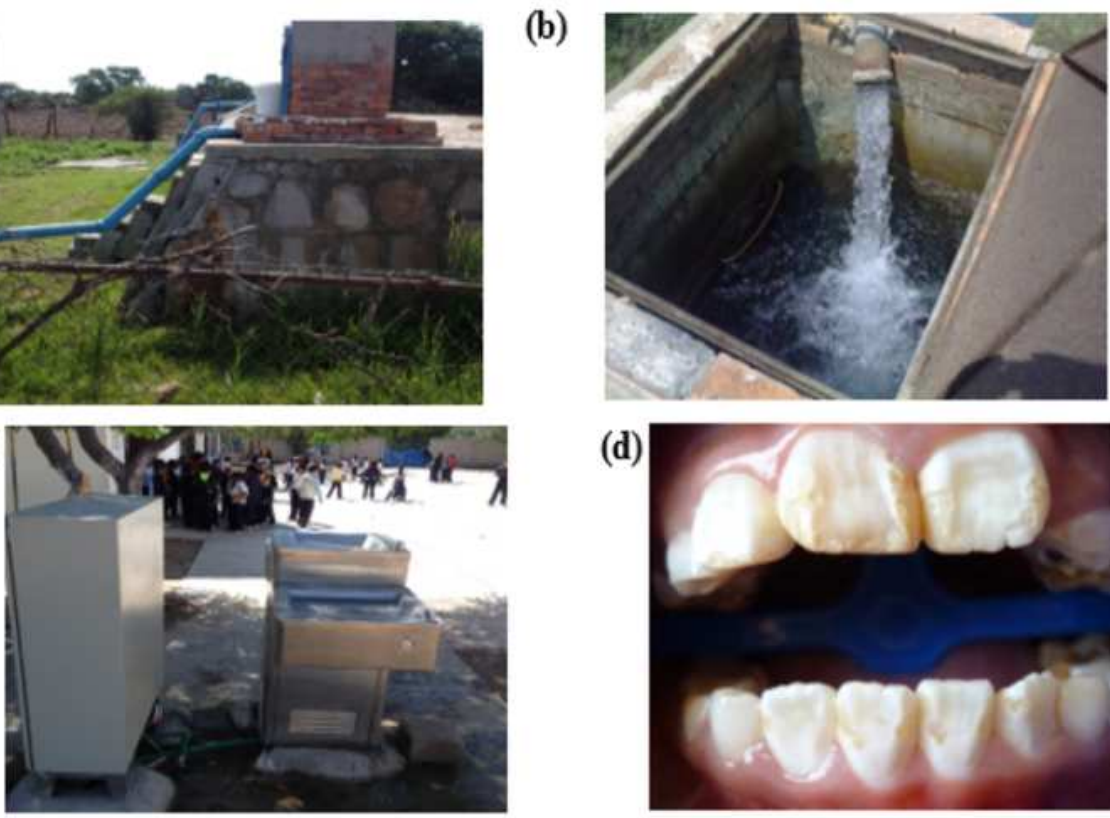

(d)

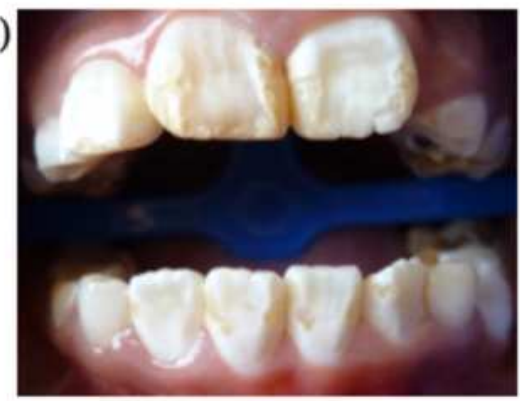

Figure 2

Laborcilla, Villa de Arriaga: (a) Location; (b) Well; (c) Water dispenser; (d) Dental fluorosis. 

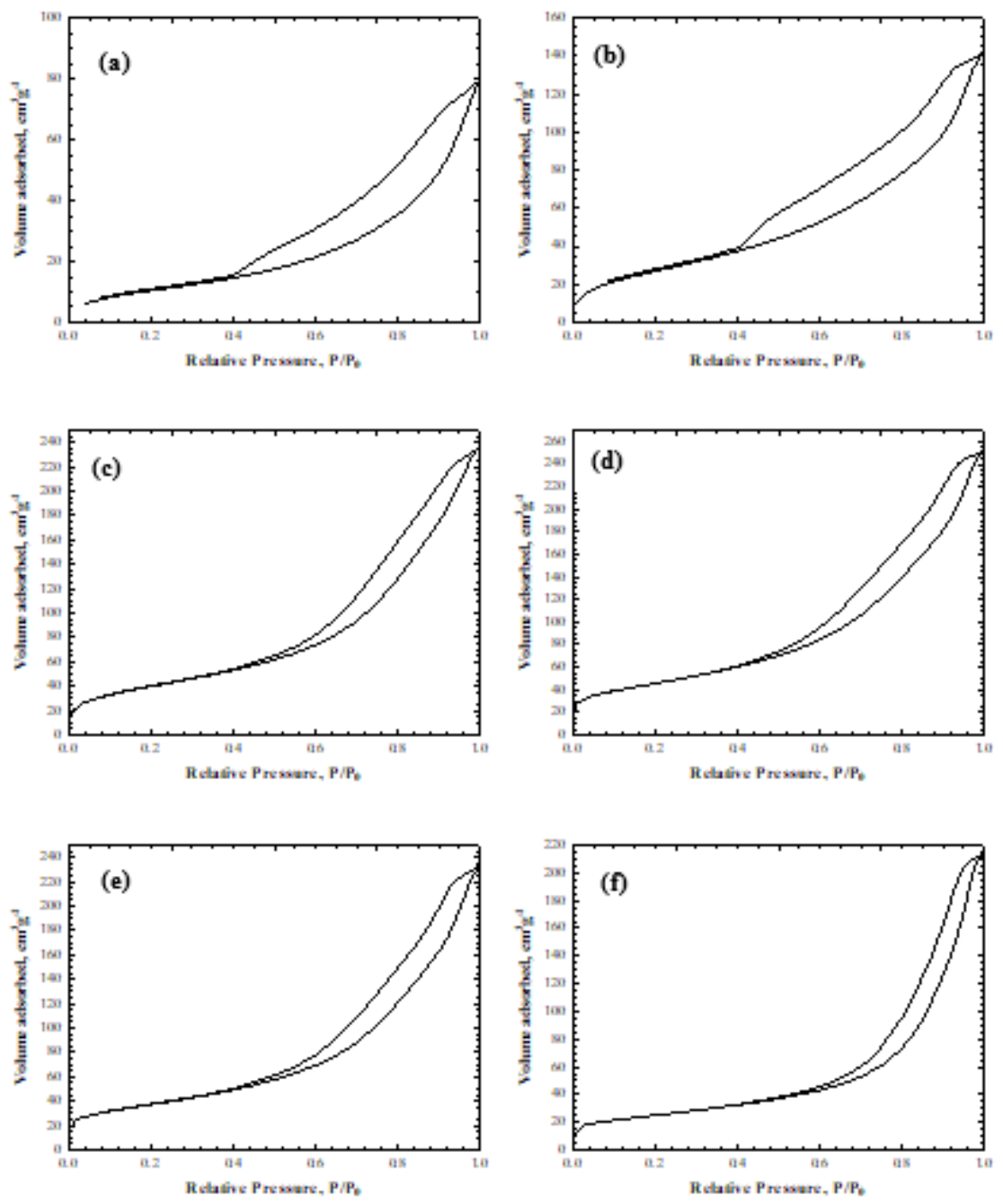

Figure 3

Nitrogen adsorption isotherms at $77 \mathrm{~K}$ of: (a) Bone; (b) C400; (c) C500; (d) C600; (e) C700; (f) C800 


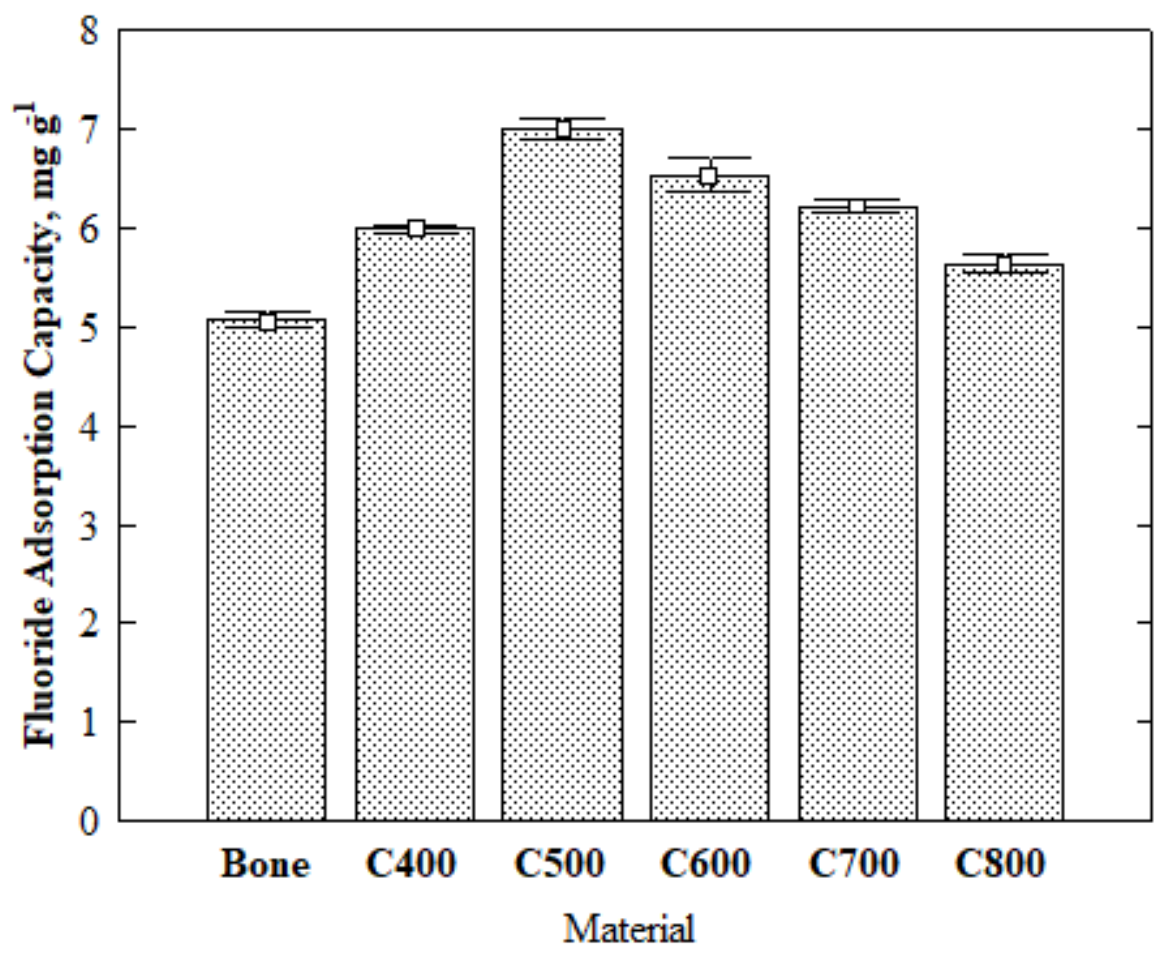

Figure 4

Influence of the pyrolysis temperature on the fluoride adsorption capacity of Bone, C400, C500, C600, C700 and C800.

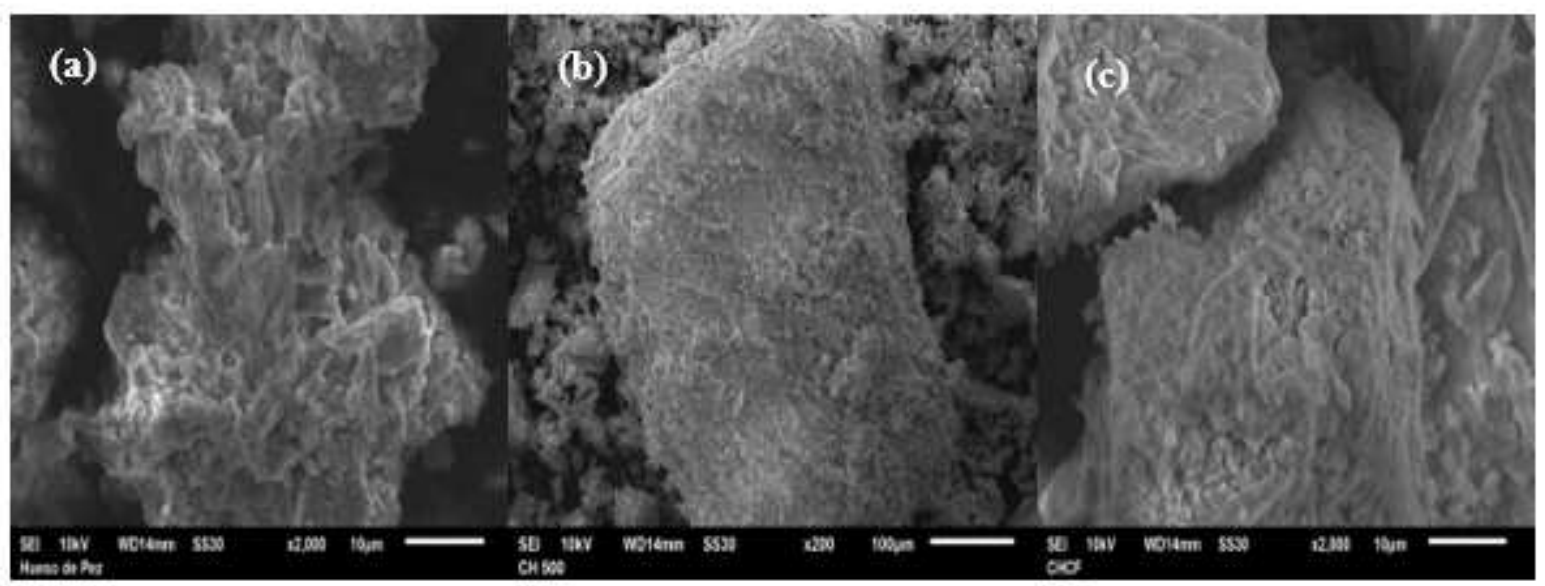

Figure 5

SEM micrographs of (a) Bone; (b) C500 and (c) CF500. 


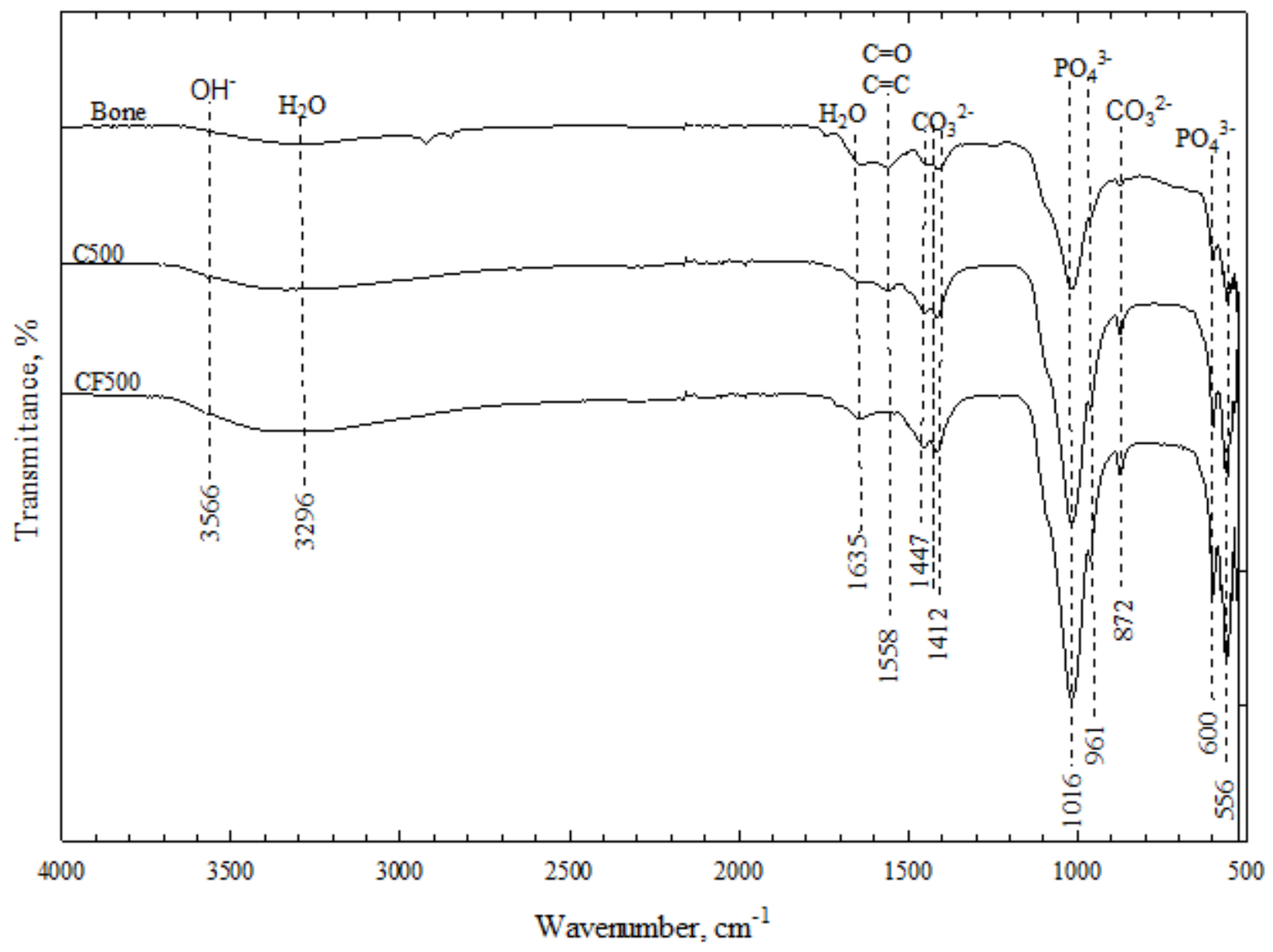

Figure 6

FT-IR spectra of Bone, C500 and CF500. 


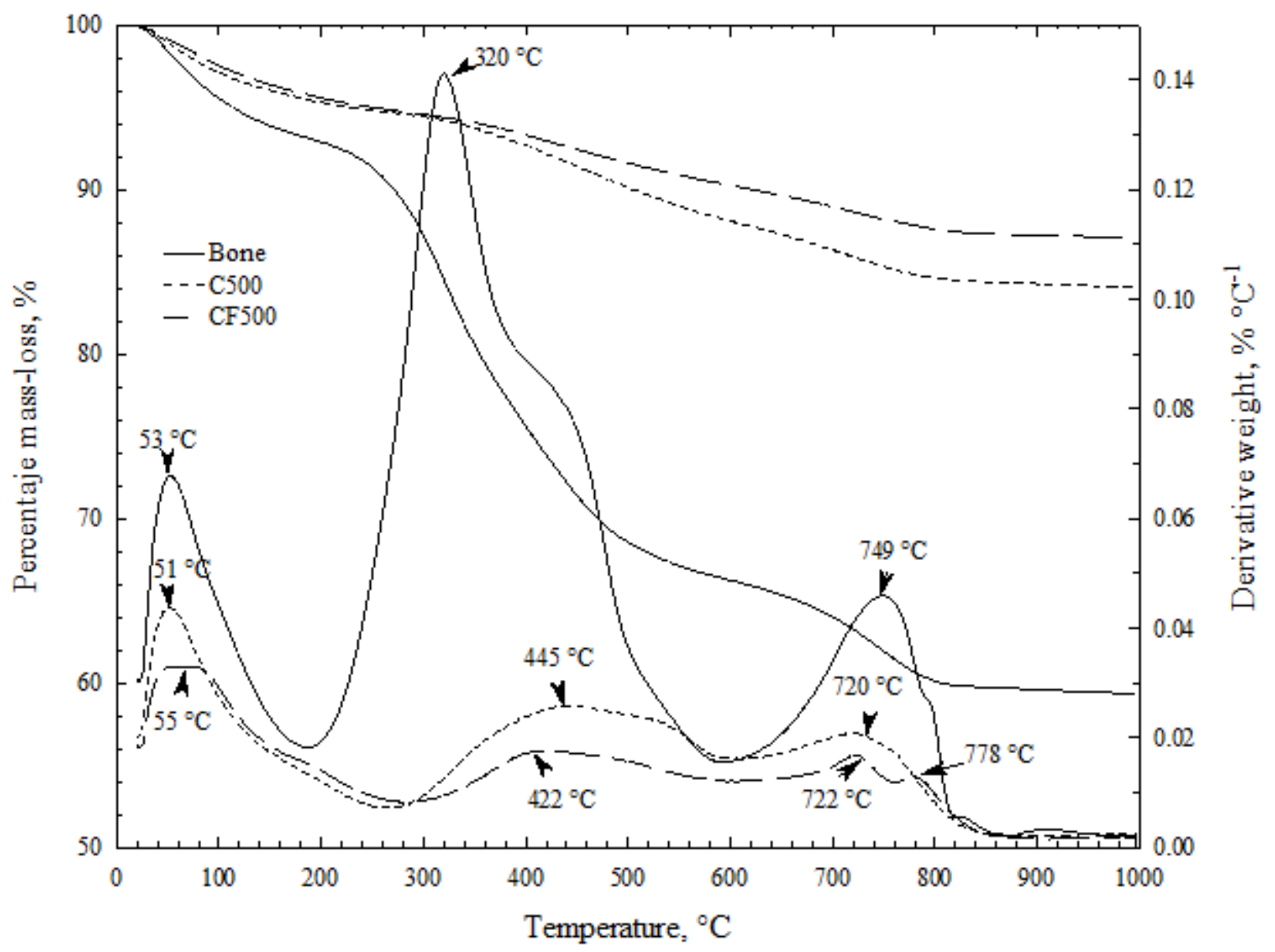

Figure 7

TGA samples of Bone, C500 and CF500. 


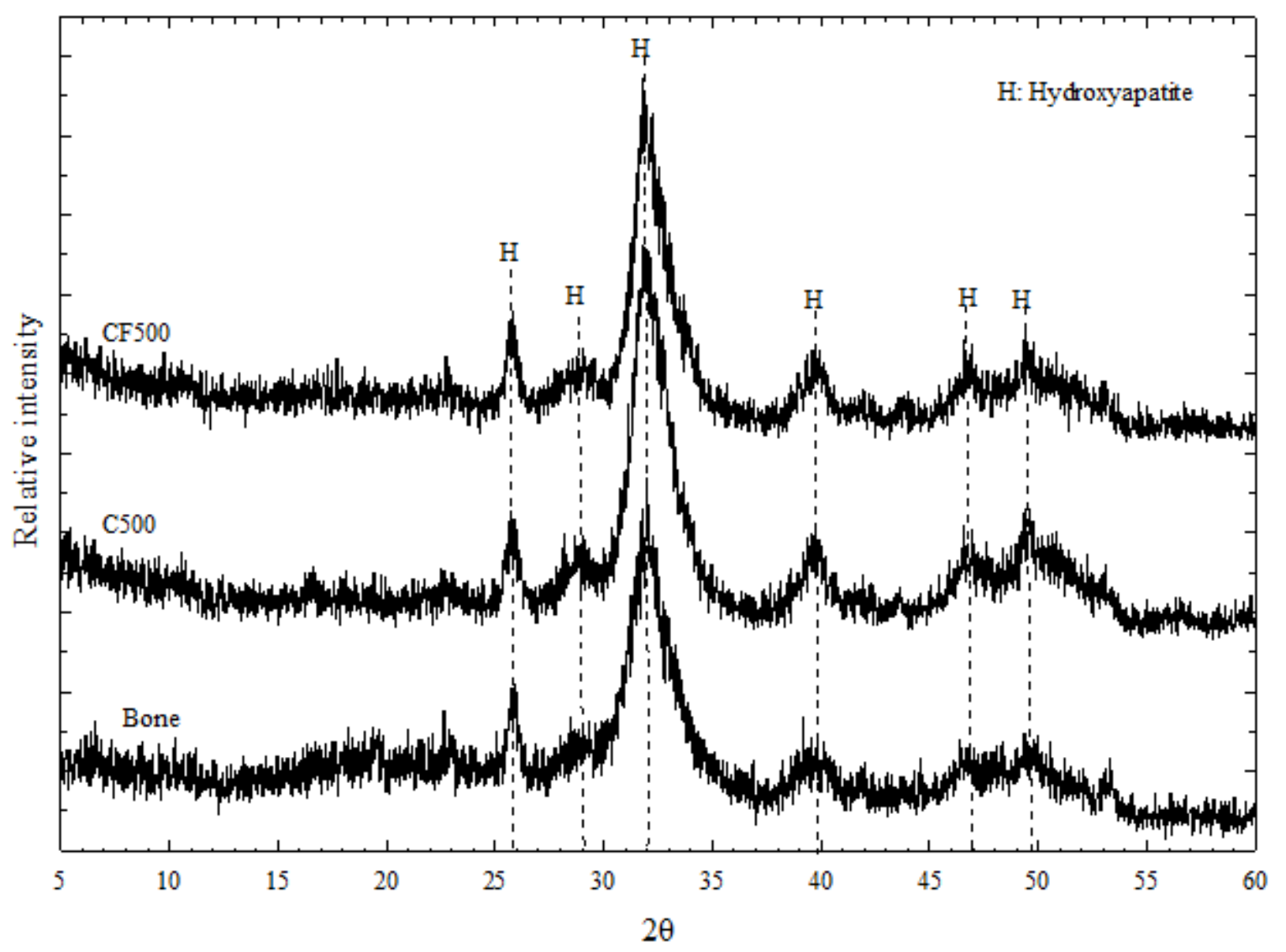

Figure 8

XRD patterns of Bone, C500 and CF500.

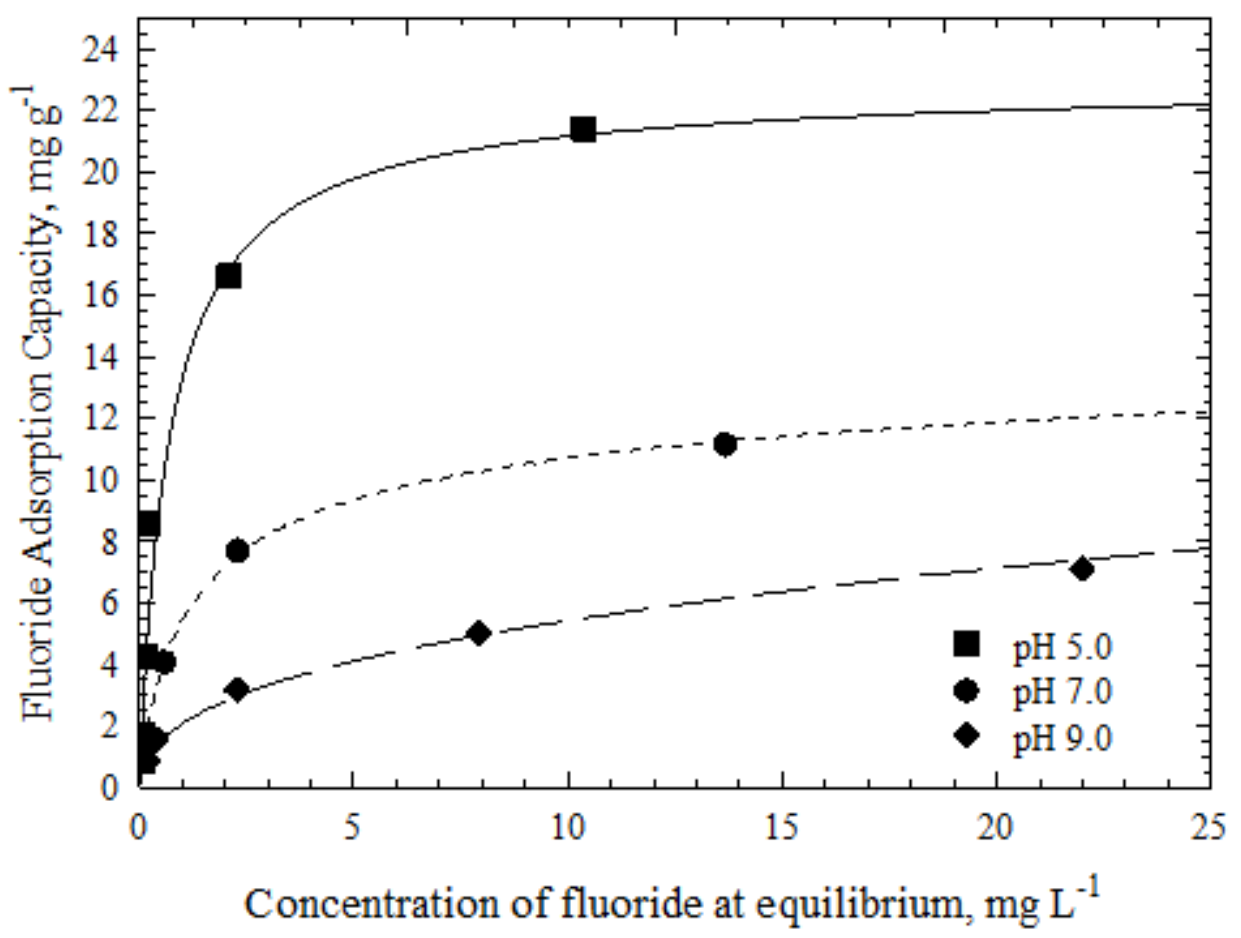


Figure 9

Effect of solution $\mathrm{pH}$ on the fluoride adsorption capacity on $\mathrm{C} 500$ at $\mathrm{T}=25^{\circ} \mathrm{C}$.

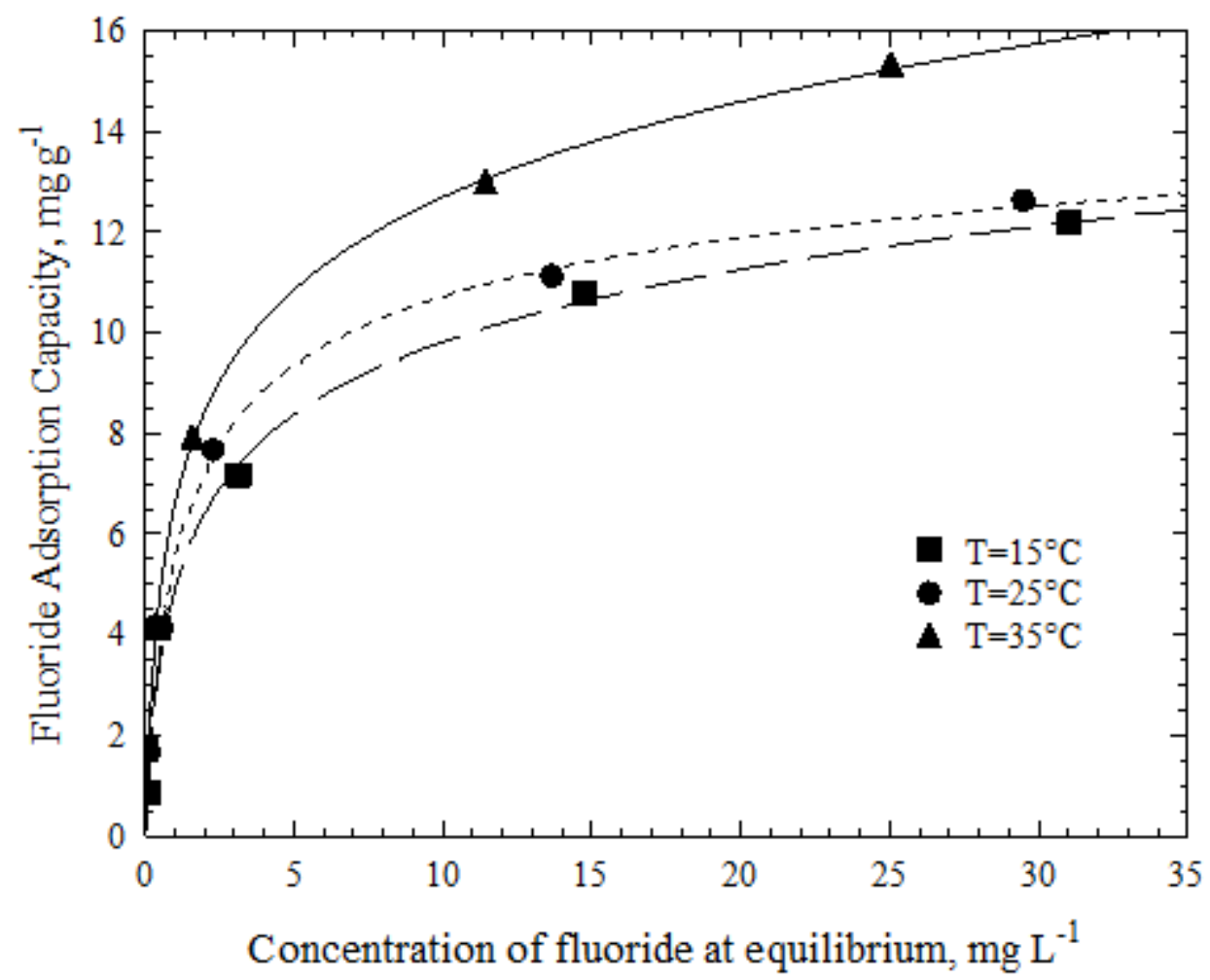

Figure 10

Effect of solution temperature on the fluoride adsorption capacity of $\mathrm{C} 500$ at $\mathrm{pH}=7.0$

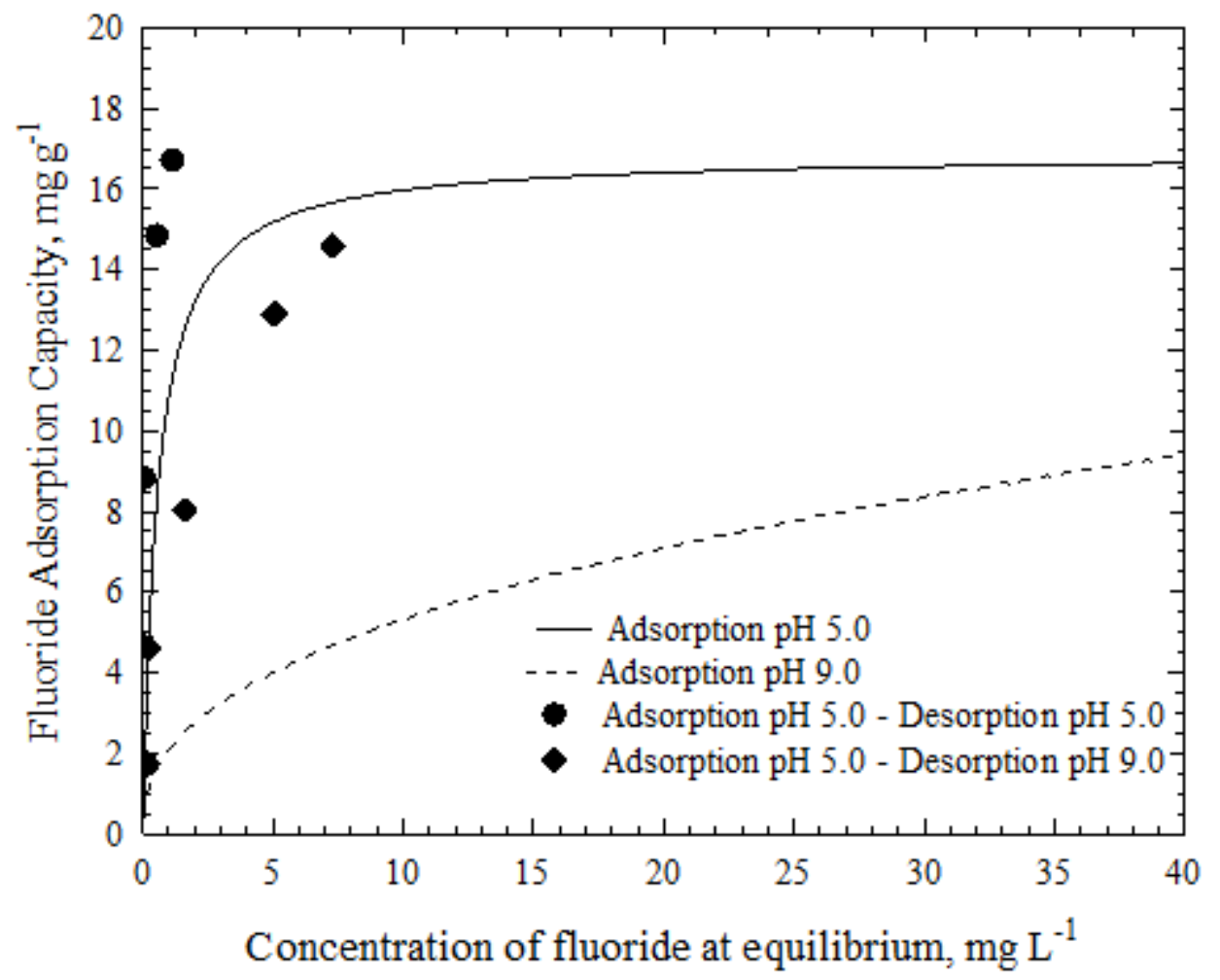


Figure 11

Fluoride adsorption-desorption equilibrium on $\mathrm{C} 500$ at different values of $\mathrm{pH}$ and $\mathrm{T}=25^{\circ} \mathrm{C}$.

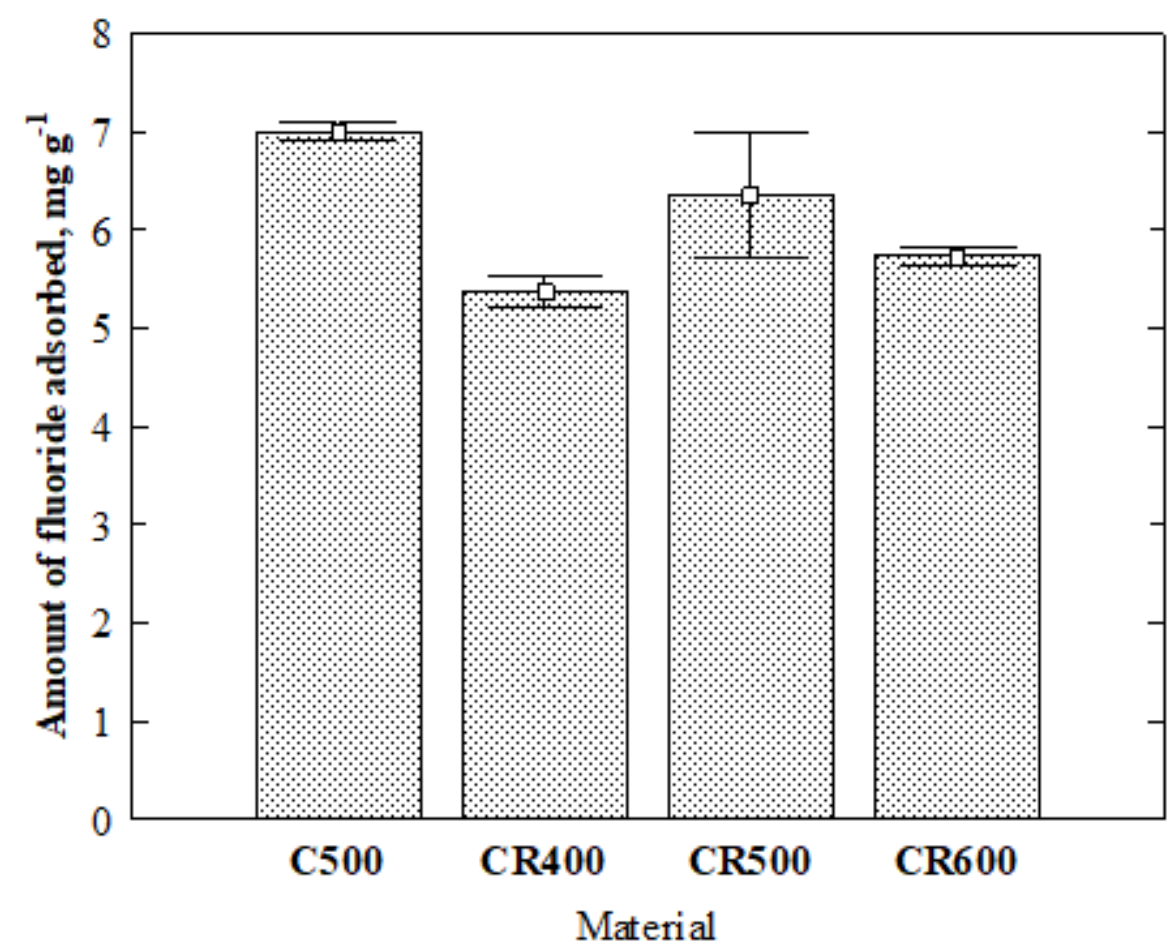

Figure 12

Fluoride adsorption capacities of bone char thermally regenerated. 